\title{
A review of oil and gas seepage in the Nuussuaq Basin, West Greenland - implications for petroleum exploration
}

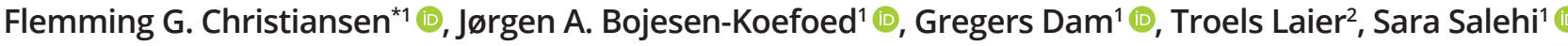 \\ ${ }^{1}$ Geological Survey of Denmark and Greenland (GEUS), Copenhagen, Denmark, ${ }^{2}$ Geological Survey of Denmark and Greenland (GEUS), Copenhagen, \\ Denmark (Emeritus)
}

\begin{abstract}
The Nuussuaq Basin in West Greenland has an obvious exploration potential. Most of the critical elements are well documented, including structures that could form traps, reservoir rocks, seals and oil and gas seepage that documents petroleum generation. And yet, we still lack a full understanding of the petroleum systems, especially the distribution of mature source rocks in the subsurface and the vertical and lateral migration of petroleum into traps. A recently proposed anticlinal structural model could be very interesting for exploration if evidence of source rocks and migration pathways can be found. In this paper, we review all existing, mostly unpublished, data on gas observations from Nuussuaq. Furthermore, we present new oil and gas seepage data from the vicinity of the anticline. Occurrence of gas within a few kilometres on both sides of the mapped anticline has a strong thermogenic fingerprint, suggesting an origin from oil-prone source rocks with a relatively low thermal maturity. Petroleum was extracted from an oil-stained hyaloclastite sample collected in the Aaffarsuaq valley in 2019, close to the anticline. Biomarker analyses revealed the oil to be a variety of the previously characterised "Niaqornaarsuk type," reported to be formed from Campanian-age source rocks. Our new analysis places the "Niaqornaarsuk type" $10 \mathrm{~km}$ from previously documented occurrences and further supports the existence of Campanian age deposits developed in source rock facies in the region.
\end{abstract}

\section{Introduction}

The exploration potential for petroleum in the Nuussuaq Basin in West Greenland (Figs 1 and 2) was first realised in the early 1990s, based on the observations of oil seepage followed by core drilling and conventional exploration drilling (Christiansen 1993, 2011; Christiansen et al. 1994a, 1994b, 1995b, 1996a, 1996b, 1997a). However, we currently lack a full understanding of the petroleum systems of the area. Although oil seeps have been widely recognised on many coastal localities and classified in detail analytically (Bojesen-Koefoed et al. 1999, 2007; Christiansen et al. 1996c), we still do not know the areal distribution of mature petroleum source rocks in the subsurface and the vertical and lateral migration of oil and gas into possible traps or to the surface.

Most recently, Sørensen et al. (2017) proposed a new play concept based on the photogrammetric mapping of inversion structures. A newly mapped large structural anticline on central Nuussuaq (Fig. 2) with expected good

\author{
*Correspondence: fgc@geus.dk \\ Received: 24 Mar 2020 \\ Accepted: 08 July 2020 \\ Published: 04 Dec 2020
}

Keywords: Nuussuaq Basin, West Greenland, gas observations, oil and gas geochemistry, anticline petroleum exploration model

\section{Abbreviations:}

DGU: Geological Survey of Denmark GGU: Geological Survey of Greenland GEUS: Geological Survey of Denmark and Greenland

GC-MS: gas chromatography-mass spectrometry

$\mathrm{GC}_{\mathrm{FID}}$ : gas chromatography-flame ionization detection

MPLC: medium-pressure liquid chromatography

GC-MS SIM: selective ion monitoring GC-MS DInSAR: Differential Synthetic Aperture Radar Interferometry NDVI: Normalized Difference Vegetation Index

GEUS Bulletin is an open access, peerreviewed journal published by the Geological Survey of Denmark and Greenland (GEUS). This article is distributed under a CC-BY 4.0 licence, permitting free redistribution, and reproduction for any purpose, even commercial, provided proper citation of the original work. Author(s) retain copyright.

Edited by: Catherine Jex (GEUS, Denmark)

Reviewed by: Chris Parry (GER X AS, now University of Stavanger, Norway) and Sverre Ohm (University of Stavanger, Norway)

Funding: See page 19

Competing interests: None declared

Additional files: See page 19 


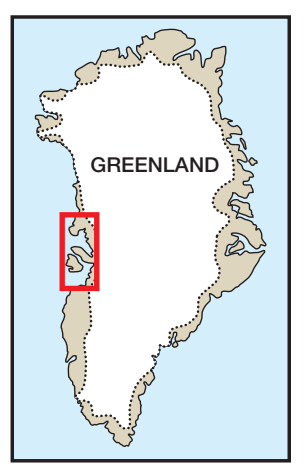

Neogene sediment cover offshore

Saqqaata Qaqqaa central complex

Undifferentiated basalts offshore

Naqerloq Formation

Svartenhuk Formation

Maligât Formation

Paleocene picrites

(Vaigat Formation)

Maastrichtian-

Paleocene sediments

Albian-Campanian

sediments

Precambrian basement

Extensional fault

_ Fault with lateral or

alternating

displacements

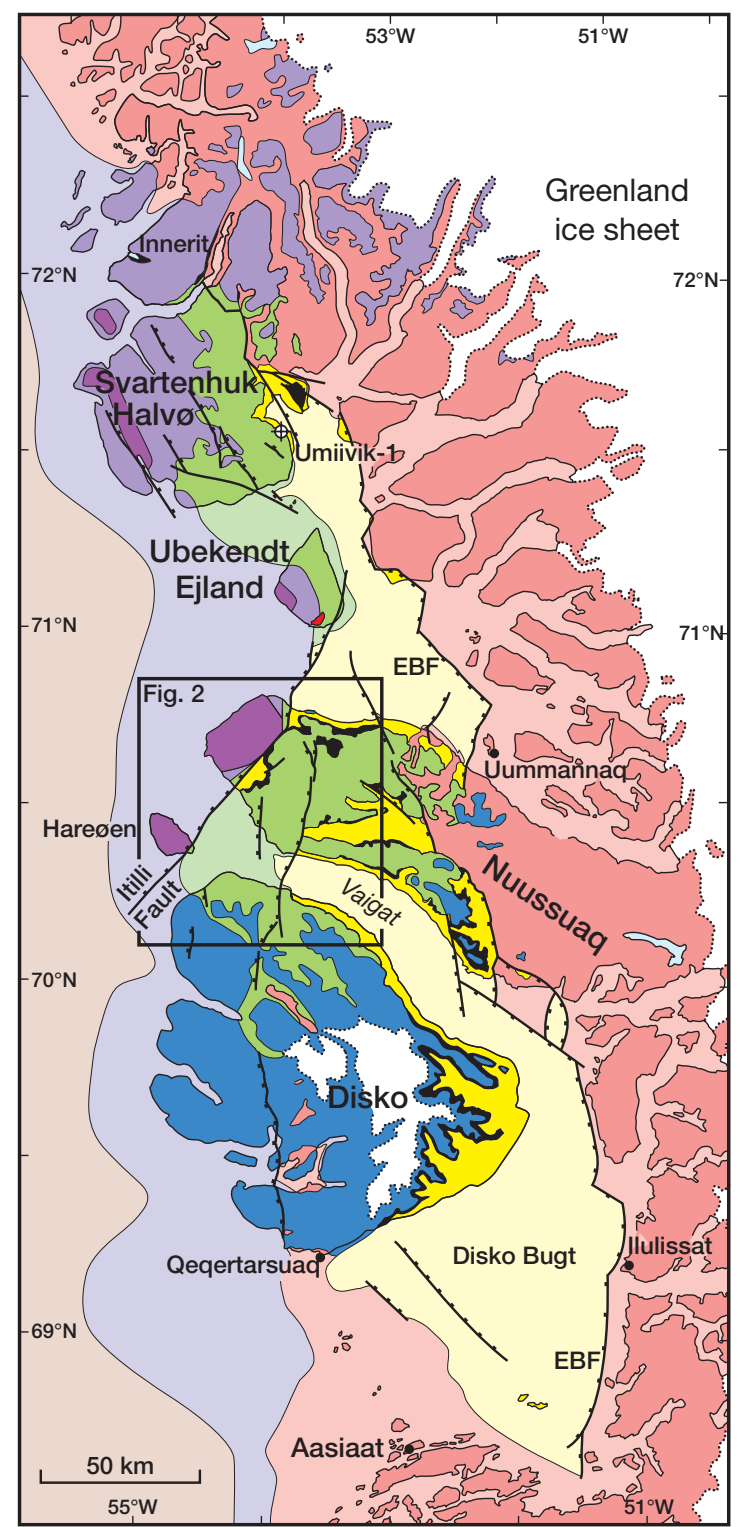

Fig. 1 Simplified geological map of the Nuussuaq Basin, West Greenland, showing the position of the outcropping sediments on Disko, Nuussuaq and Svartenhuk Halvø. EBF: Eastern Boundary Fault. Location of Umiivik-1 core is indicated. For the purpose of this paper, Nuussuaq Basin refers to the area shown in this figure. reservoirs and seals is an obvious exploration target if mature source rocks and migration pathways can be demonstrated. To understand this target and to provide the necessary input for a risk assessment, we need to further document oil and gas seepage in the inland areas, especially along and east of the Kuugannguaq-Qunnilik Fault zone in central Nuussuaq (Fig. 2). Compared to the numerous oil seeps along the coasts of Disko and Nuussuaq, only a few records have been obtained inland, where exploration logistics are more complicated and costs are higher. Also, freshly eroded rocks along the coast seem to better preserve oil than inland exposures, where volcanic rocks weather differently due to frequent melting and freezing processes and often alter to rocks with a distinct smell of soil.

Less attention has been paid to document the occurrences of gas in the Nuussuaq Basin, although some preliminary data were obtained during systematic analyses of boreholes drilled by the Geological Survey of Greenland (GGU), which later merged with the Geological Survey of Denmark to form the Geological Survey of Denmark and Greenland (GEUS) and industry. Unfortunately, in a number of these records, gas was not sampled and documented properly or at all. This paper presents a systematic review of all gas observations and data in the Nuussuaq Basin in order to understand the petroleum systems and aid future exploration. Here, we (1) summarise existing data for gas accumulations, much of which were, until now, only available in unpublished GGU and GEUS reports and (2) present new critical data based on samples collected in 2019. These new data are important to characterise oil and gas seepage near to the Kuugannguaq-Qunnillik Fault zone, where future drilling is being considered. 


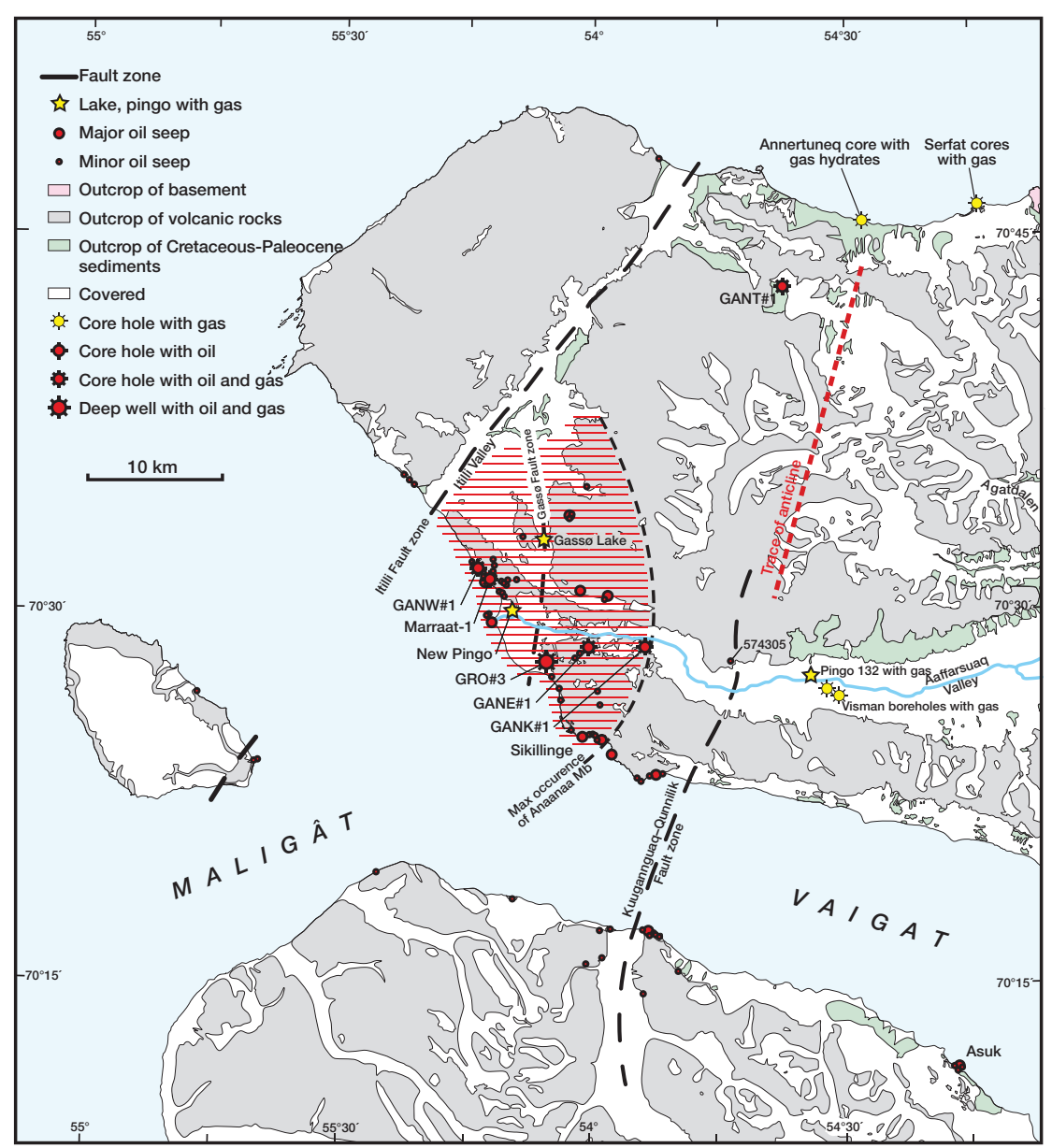

Fig. 2 Simplified geological map of northern Disko and western Nuussuaq in the Nuussuaq Basin. Location of wells and cores with oil and gas, major and minor oils seeps, localities with various types of gas observations and the approximate position of the anticline from Sørensen et al. (2017; red-dashed line) are marked.

\section{Geological setting and exploration models of the Nuussuaq Basin}

The Nuussuaq Basin is a rift basin that developed during Cretaceous - Paleocene due to extension between Canada and Greenland. The basin is characterised by outcropping sediments on Disko, Nuussuaq and Svartenhuk Halvø. The southern limit is located around Qeqertarsuaq, Disko (Fig. 1), but the northern and western limits are less well defined. For the purposes of this paper, Nuussuaq Basin corresponds to the area shown in Fig. 1. The sediments of the Nuussuaq Basin and the overlying volcanic rocks are well exposed throughout the Disko-Nuussuaq-Svartenhuk Halvø region and are important to understand the sedimentology, stratigraphy, depositional and subsidence history of the sedimentary basins in West Greenland. The Nuussuaq Basin has been intensively studied as an analogue for offshore basins. Most of these studies are based on large field campaigns in 1991-1997 and 2004, combined with many shorter field trips (Christiansen 1993; Christiansen \& Pulvertaft 1994; Christiansen et al. 1992, 1995a, 1996a, 1997a, 1998). For an overview of previous research and exploration history, see Dam et al. (2009) and Christiansen (2011).
The present paper focuses on the parts of the Nuussuaq Basin on western and central Nuussuaq between the Itilli and the Kuugannguaq-Qunnilik Fault zones (Fig. 2). In this part of the Nuussuaq Basin, the sedimentary succession is covered by a few kilometres of volcanics of the Vaigat and Maligât Formations (Figs 1-3; Pedersen et al. 2017, 2018). The underlying sediments were mainly characterised by drilling or from field work on exposures in the Itilli Valley, along the Itilli Fault zone (Figs 1 and 2).

The known sedimentary succession is dominated by marine sediments of mid-Cretaceous to Palaeogene age. A general facies change occurs from deltaic and slope sediments close to the Kuugannguaq-Qunnilik Fault zone to deeper marine turbidites in and around the Itilli Fault zone (Dam et al. 2009). Many mudstone intervals occur in the Itilli and Kangilia Formations (Dam et al. 2009); some of these may represent possible source rocks and many are likely to have good sealing capacities (Fig. 3). The most likely reservoir intervals are turbidite sandstones in the Itilli Formation and incised valley sandstones of the Quikavsak and Agatdal Formations and their equivalents (Dam \& Sønderholm 1994, 1998; Dam et al. 2009; Hjuler et al. 2017; Kierkegaard 

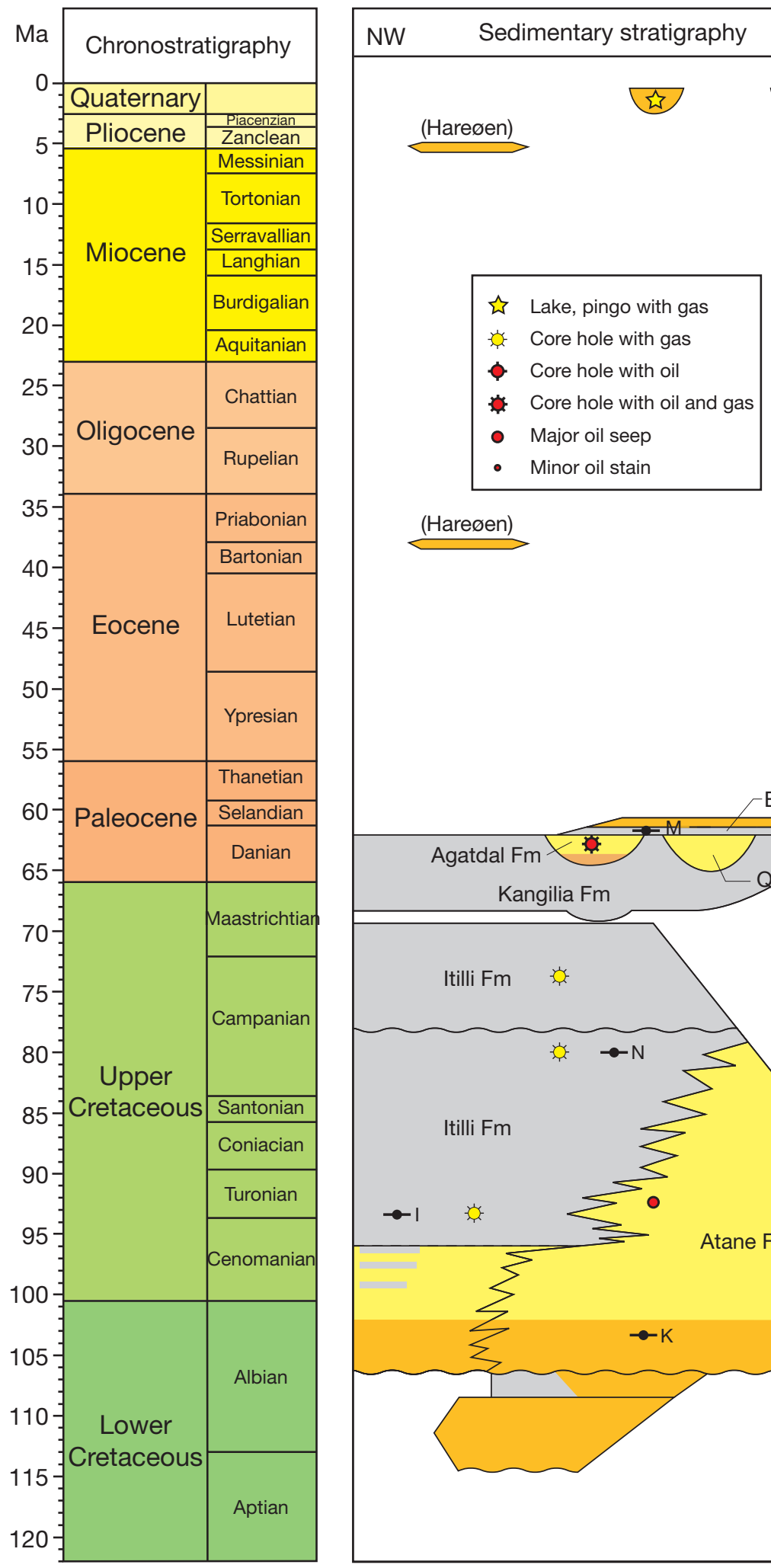

SE

NW

Volcanic stratigraphy
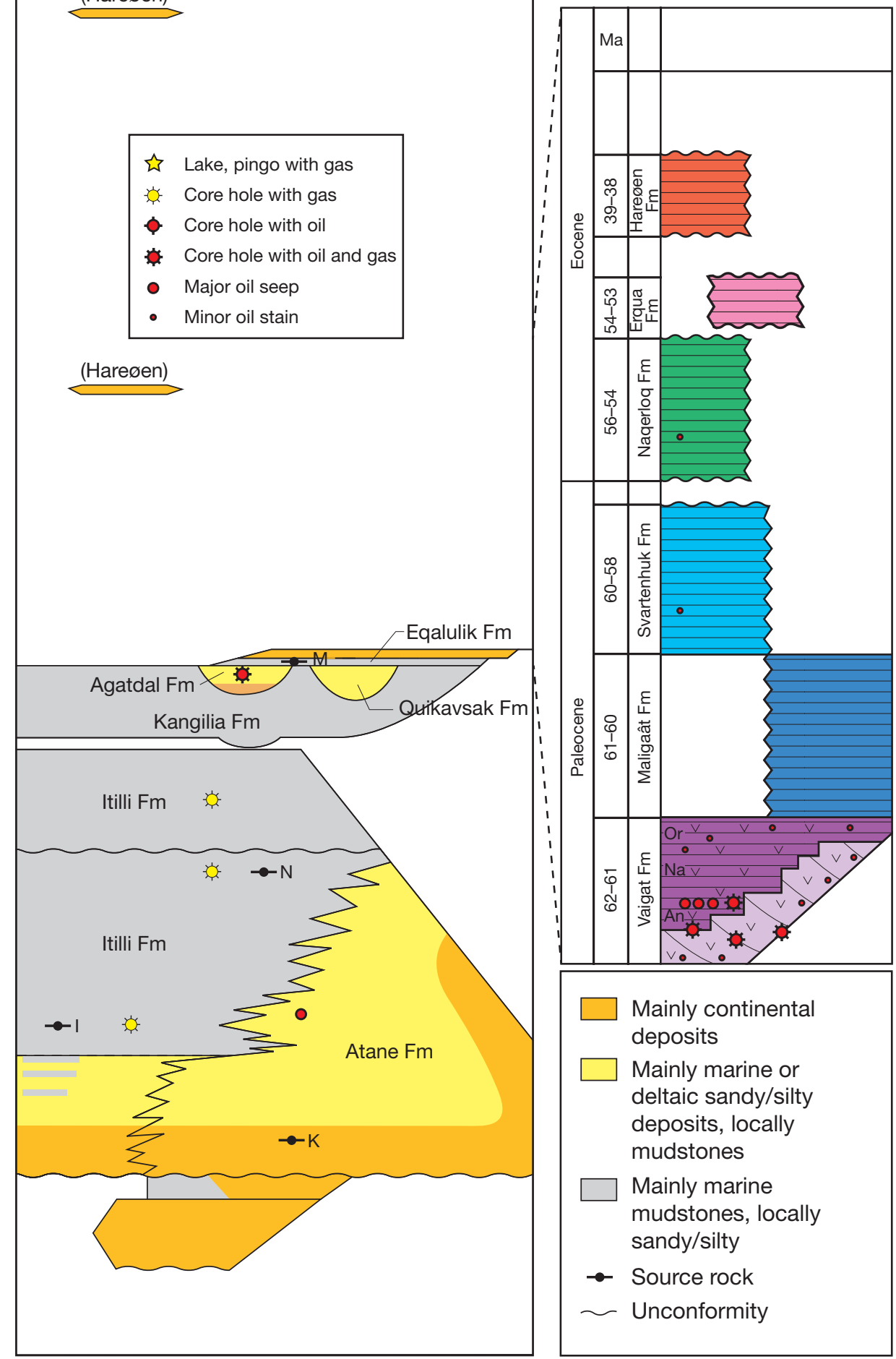

Mainly continental deposits

$\square$ Mainly marine or deltaic sandy/silty deposits, locally mudstones

Mainly marine mudstones, locally sandy/silty

$\rightarrow$ Source rock

〜nconformity

Fig. 3 Simplified sedimentary and volcanic stratigraphy of the Nuussuaq Basin on Disko, Nuussuaq and Svartenhuk Halvø. The relationship between petroleum seeps and stains and main petroleum systems elements is shown. Possible ages for source rocks of the following oil types are shown: M: Marraat type; N: Niaqornaarsuk type; I: Itilli type; K: Kuugannguaq type. The Eqalulik type source rock is not known, but it is assumed to be early Cretaceous. Many of the petroleum stains in the Vaigat Formation are associated with later Eocene dykes. Vaigat Formation includes the following: An: Anaanaa Member; Na: Naujánguit Member; Or: Ordlingassoq Member. Note that the Eocene volcanic units are rather thin and not regionally distributed. Hareøen Formation is only found on Hareøen, Erqua Formation only on Ubekendt Ejland and Naqerloq Formation only on Hareøen and westernmost parts of Nuussuaq, Ubekendt Ejland and Svartenhuk Halvø. Based on Sørensen et al. (2017), Dam et al. (2009) and Pedersen et al. (2017, 2018). 
1998). The most likely traps are extensional-rotated fault blocks formed in the Cretaceous or Palaeogene, or late Paleocene inversion structures such as the anticline mapped by Sørensen et al. (2017).

Nuussuaq experienced a short, but very intensive, exploration phase in 1994-1998, driven largely by new, and at that time unpublished, data on oil seepage. The small Canadian company grønArctic Energy Inc. managed to drill four fully cored stratigraphic boreholes (GANW\#1, GANE\#1, GANK\#1, and GANT\#1) and one deep wildcat well (GRO\#3) in 1994-1996. But, despite many encouraging oil shows and documentation of good reservoirs and seals in the Upper Cretaceous and Palaeogene succession, the company was unable to raise funding for further drilling and they eventually relinquished their licences in May 1998.

\section{Existing data from oil seeps and bore holes in the Nuussuaq Basin}

The first oil-seeps on Nuussuaq were discovered in the Marraat area in 1992 (Christiansen 1993). Since then, significant time and resources have been invested to find additional localities, especially along the coast, with evidence of either visible oil seepage or micro-seepage in mineralised veins. Oil seepage is very common in an area on western Nuussuaq (Christiansen et al. 1996c). Following the years of systematic field work, evidence of oil has also been found in many other localities, including Disko, Hareøen, Ubekendt Ejland and Svartenhuk Halvø (Figs 1 and 2).

Several hundred samples of oil seeps or oil-impregnated cores on Nuussuaq were analysed in detail by Bojesen-Koefoed et al. (1997a, 1999), and supplemented more recently by Bojesen-Koefoed et al. (2007). They described the characteristics of the oil samples from the region and grouped them into five distinct oil types. These types are adopted here, but for a complete overview of the oil-type classification, we refer the reader to Bojesen-Koefoed et al. (1999, 2007). The main models of source rock distribution, depositional environment and generative history of the source rocks are based on state-of-the-art analyses and are documented in detail (Bojesen-Koefoed et al. 1999, 2004, 2007; Christiansen et al. 1996c). Some of the oils have a unique composition of biological markers, containing organic compounds such as lupanes and a series of norhopanes that were only rarely documented at the time of analyses (Nytoft et al. 2000, 2002).

Understanding the distribution and concentration of different oil types is important for petroleum exploration on Nuussuaq. Previous studies demonstrated working petroleum systems and first indications of where the source rocks could be expected in the subsurface, where and when they have generated oil and how migration, and in some cases degradation, took place. The oils so far recorded in the Nuussuaq Basin occur in two main settings:

1. In oil-impregnated porous lavas and hyaloclastites that may have formed exhumed continuous reservoirs in the deeper part of the volcanic succession, especially within the Anaanaa Member of the Vaigat Formation (Pedersen et al. 1998) or just below, in the uppermost part of the sedimentary successions (Fig. 3). Oil-impregnated rocks hold large volumes of hydrocarbons, which were generated, and probably migrated vertically, from an underlying source rock such as oil of the "Marraat deltaic type" or the lesser known "Eqalulik type" or "Niaqornaarsuk type" (as defined by Bojesen-Koefoed et al. 1999). This migration likely occurred during and shortly after the main phase of volcanism in the region (62-60 Ma) with rapid subsidence and possibly increased heat flow. Such oils occur over large parts of western Nuussuaq, especially in the area from Marraat-1-GANE\#1Sikillinge (Fig. 2), where several billion barrels of more or less degraded oil may fill out most available porosity in the volcanics (Christiansen et al. 2006; see Supplementary File S6).

2. In migration conduits, especially along faults, dykes, fractures or as fluid inclusions in thin mineralised veins in many different volcanic units (Fig. 3). Oils also occur in some sands in the Asuk area on Disko (Fig. 2). Such oils are generally low in volume and concentration, but are known from large areas on Disko, Nuussuaq, Ubekendt Ejland and Svartenhuk Halvø, where they often belong to the "Itilli type," presumed to be generated from a marine mid-Cretaceous source rock (Fig. 3; Bojesen-Koefoed et al. 1999, 2007).

The first setting offers some possibilities for local exploration, especially in incised valley deposits of the Lower Paleocene Quikavsak and Agatdal formations on western Nuussuaq. The area of exploration interest is, however, rather small with complex structural features that are not likely to define large targets. The second setting suggests good exploration opportunities over much larger areas in the deeper part of the Cretaceous succession and supports the anticlinal model suggested by Sørensen et al. (2017).

The main area of known oil seeps and stains was significantly enlarged after numerous field seasons. It is likely that the area containing oil of the "Marraat type" can be further extended inland towards the north and northeast. The easternmost record of the "Marraat type" is the GANK\#1 borehole. It is unclear whether this oil 
type can be traced further into the Kuugannguaq-Qunnillik Fault zone (Fig. 2). The main challenge for future oil seep studies is to find more examples from the second setting, especially along a possible fairway from northern Nuussuaq along the anticline to central and southern Nuussuaq. The major fault zones in the region are also interesting targets for future studies, as they may have been important migration pathways.

\section{Existing records of gas in the Nuussuaq Basin}

Well-documented analytical records of gas observations in the Nuussuaq Basin are relatively few. There are some historical observations of gas leakages from lakes or pingos, but they have not been analysed with modern analytical methods. More recent records were obtained during drilling campaigns, which revealed a high likelihood of widely distributed gas under pressure in the subsurface of the Nuussuaq Basin, either below a permafrost seal or deeper in the sedimentary succession. Since 1992, improved sampling techniques were developed for drilling and field work by the GGU and later by GEUS, which ensured a better understanding of gas distribution in the subsurface. Here, we review all known records of gas observations in chronological order and describe the various sampling techniques used, their limitations, to provide key results and make preliminary interpretations.

\subsection{Numerous GGU boreholes, drilled in 1992}

Numerous cores were drilled at Agatdalen (Fig. 2), Annertuneq (Fig. 2) and Svartenhuk Halvø (same location as Umiivik-1; Fig. 1) in 1992. These shallow fully cored boreholes were drilled to depths between 45 and $95 \mathrm{~m}$ by GGU using a custom-made light-weight rig that could be mobilised using small helicopters. The main goal was to document the presence of oil-prone source rocks within the marine Cretaceous succession (Fig. 3; Christiansen 1993; Christiansen et al. 1994c).

Core samples for gas analysis were taken in metal tubes. Results were reported by Laier (1994) in an unpublished institutional report, which is provided here as Supplementary File S1. Gas amounts were relatively low, which precluded stable isotopic analysis. Methane concentrations were low relative to ethane, propane and butane, which suggest preferential leakage of lighter molecules. For this reason, cans were used in subsequent studies, replacing the tubes. During the drilling at Annertuneq (core number 400407), white to bluish gas hydrates were observed at a depth of c. $7 \mathrm{~m}$ (Fig. 4). At the time of drilling, it was not realised that the material was gas hydrates and samples evaporated before they could be properly described and secured for analysis.

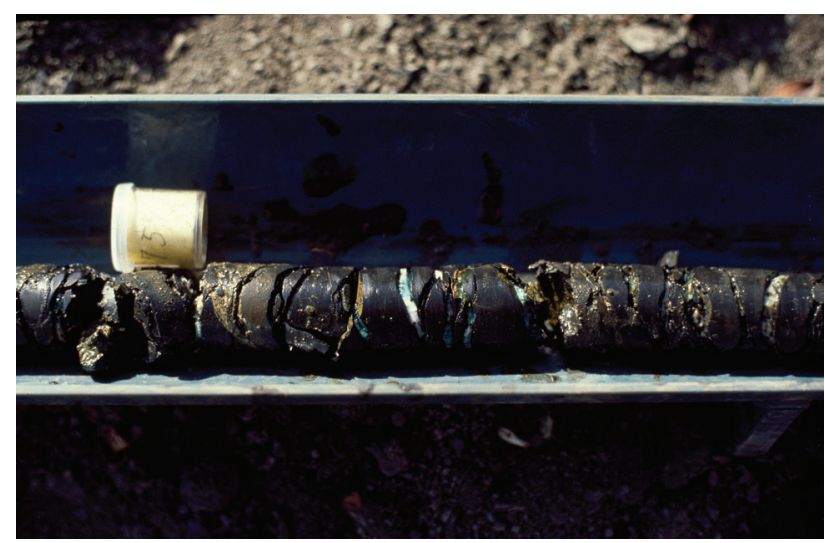

Fig. 4 Bluish gas hydrates at c. 7 m depth in core 400407 at Annertuneq on the north coast of Nuussuaq (location in Fig. 2). Core diameter is $3.0 \mathrm{~cm}$. Photo taken on 1 August 1992.

\subsection{Marraat-1 core, drilled in 1993}

Marraat-1 (408001) core (location Fig. 2; sample numbers 408011 and 408020 in Table 1) was drilled by the Canadian company Falconbridge Ltd. for GGU in August 1993. It terminated at a depth of $448 \mathrm{~m}$. The well was subsequently logged in October-November 1993 and some additional fluid samples of formation water were taken. The main goal was to clarify if the solid bitumen found at the surface was an indication of undegraded oil in the subsurface (Christiansen et al. 1994a; Dam \& Christiansen 1994).

The subsequent analytical programme focused on the oil composition that suggested new models for age and depositional environment of the source rock (Bojesen-Koefoed et al. 1999; Christiansen et al. 1994b, 1996c). Some core pieces were sealed in cans for subsequent gas and formation fluid analyses. These data were reported by Laier (1994; see Supplementary File S1) and Christiansen et al. (1995b) and are summarised in Table 1. Two samples of a rather dry gas had a sufficient concentration of methane to allow analysis of stable carbon isotopes. Values of $\delta^{13} \mathrm{C}\left({ }^{13} \mathrm{C} /{ }^{12} \mathrm{C}\right)$ and wetness indicate a mixed thermogenic biogenic origin (Table 1; Fig. 5).

\subsection{Falconbridge mineral exploration cores, drilled in 1994}

During their mineral exploration programme for nickel sulphides in 1994, Falconbridge Ltd. observed gas bubbles and froth on core surfaces. They penetrated a zone of pressured gas at c. $290 \mathrm{~m}$ depth in one of the boreholes in the Serfat area (core number FP94-11-04; Fig. 2). The gas was found in Cretaceous sediments below thick sills on the north coast of Nuussuaq (Dam \& Nøhr-Hansen 1995).

Five samples of gas were obtained from the cores and stored in plastic containers. Data were provided 


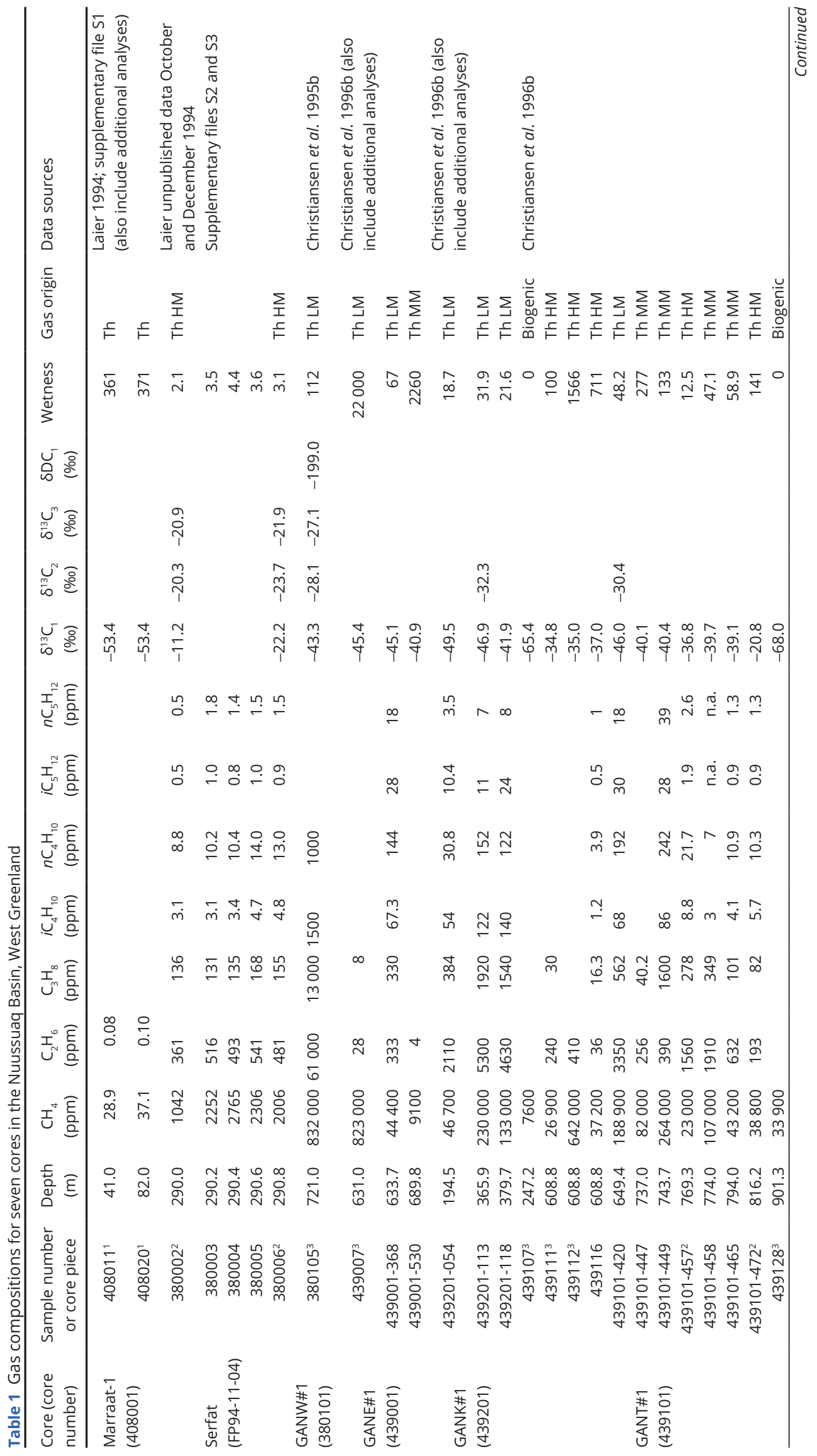




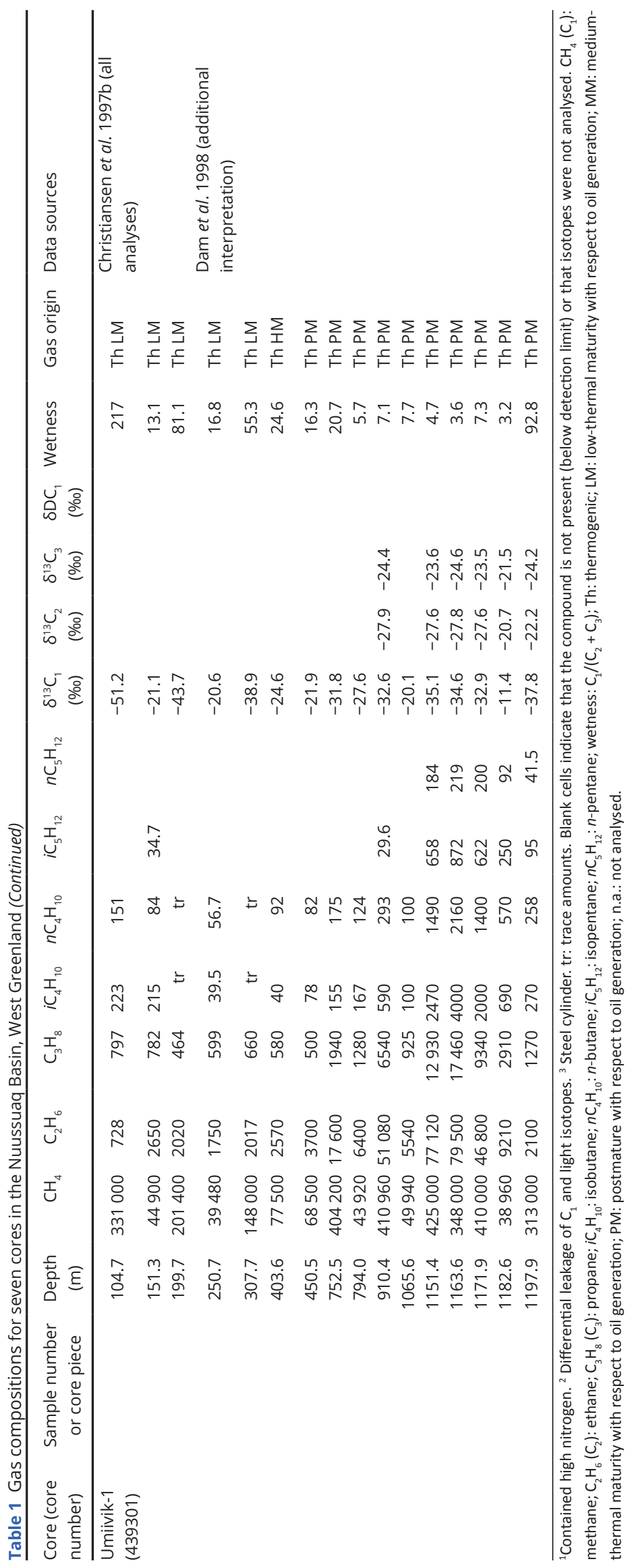


by Laier in October and December 1994 as unpublished data (see Supplementary Files S2 and S3, respectively) and are summarised in Table 1 . The samples contained significant volumes of gas with relatively high concentrations (up to $3000 \mathrm{ppm}$ ) of wet gases. C-isotope composition of methane $\left(\delta^{13} C_{1}\right)$, ethane $\left(\delta^{13} C_{2}\right)$ and propane $\left(\delta^{13} C_{3}\right)$ suggested a thermogenic origin from a source rock with a relatively high thermal maturity. The data suggested a loss of lighter isotopes by diffusion from the plastic containers (Table 1). This was tested by experiments of the containers (Laier, unpublished data, December 1994; Supplementary File S3).

\subsection{GANW\#1, drilled in 1994}

GANW\#1 (core 380101, Fig. 2) was drilled by grønArctic Energy, Calgary, Canada in September-October 1994 as a follow-up to the Marraat-1 borehole (Christiansen et al. 1995a). The main goal was to penetrate the base of the volcanic succession and to document further oil impregnation at depth.

One gas sample (380105) from a depth of $721 \mathrm{~m}$ was sampled from the wellhead in a steel cylinder, and a full suite of gas analyses was carried out. The data were reported by Christiansen et al. (1995b) and are presented in Table 1. The gas had a moderate wetness (Table 1 ; Fig. 5 ). $\delta^{13} C_{1}$ versus $\delta D$ of methane $\left(\delta D C_{1}\right)$ suggests a thermogenic origin from a source rock and an

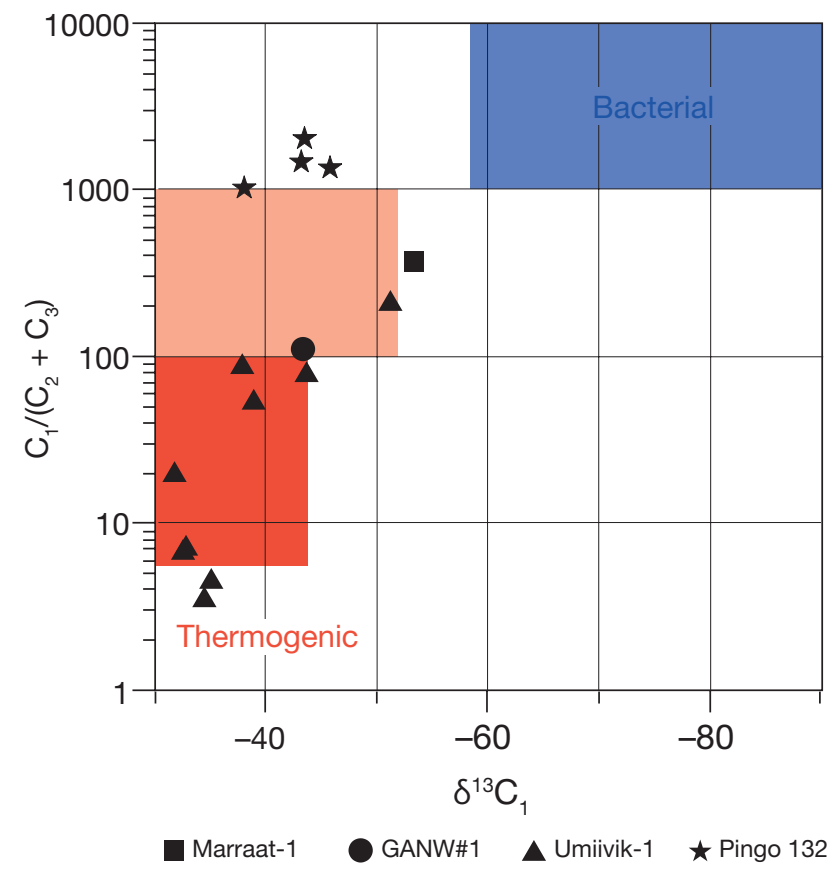

Fig. 5 Wetness $\left(\mathbf{C}_{1} / \mathbf{C}_{2}+\mathbf{C}_{3}\right)$ versus $\delta^{13} \mathbf{C}$ of methane $\left(\boldsymbol{\delta}^{13} \mathbf{C}_{1}\right)$ for Marraat-1, GANW\#1, Umiivik-1 and Pingo 132. $\mathbf{C}_{1}$ : methane; $\mathbf{C}_{2}$ : ethane; $\mathbf{C}_{3}$ : propane. Compositional fields indicate biogenic or thermogenic origin. Modified from Schoell (1984). association with oil (Fig. 6), while $\delta^{13} C_{1}$ versus $\delta^{13} C_{2}$ suggests a low thermal maturity dominated by type III kerogen (Fig. 7; Christiansen et al. 1995b).

\subsection{GANE\#1, GANK\#1 and GANT\#1, drilled in 1995}

Three fully cored boreholes GANE\#1 (core 439001), GANK\#1 (core 439201) and GANT\#1 (core 439101) and one sidetrack (GANE\#1A; data not shown here) were drilled by grønArctic Energy in the summer of 1995 to depths of between 398 and $901 \mathrm{~m}$ as part of their exploration and production license on western Nuussuaq (locations in Fig. 2). The main goal was to characterise the sedimentary succession below the volcanic succession and to demonstrate an active petroleum system. All boreholes revealed oil and gas within volcanic or sedimentary rocks. Detailed sedimentological and stratigraphical studies and comprehensive geochemical analyses of organic compounds were carried out by GGU for grønArctic Energy (Christiansen et al. 1996b). Some of these data are presented in Table 1.

Some gases sampled in steel cylinders together with gas from core-pieces sealed in cans were analysed. Gas was commonly observed in many intervals in GANT\#1

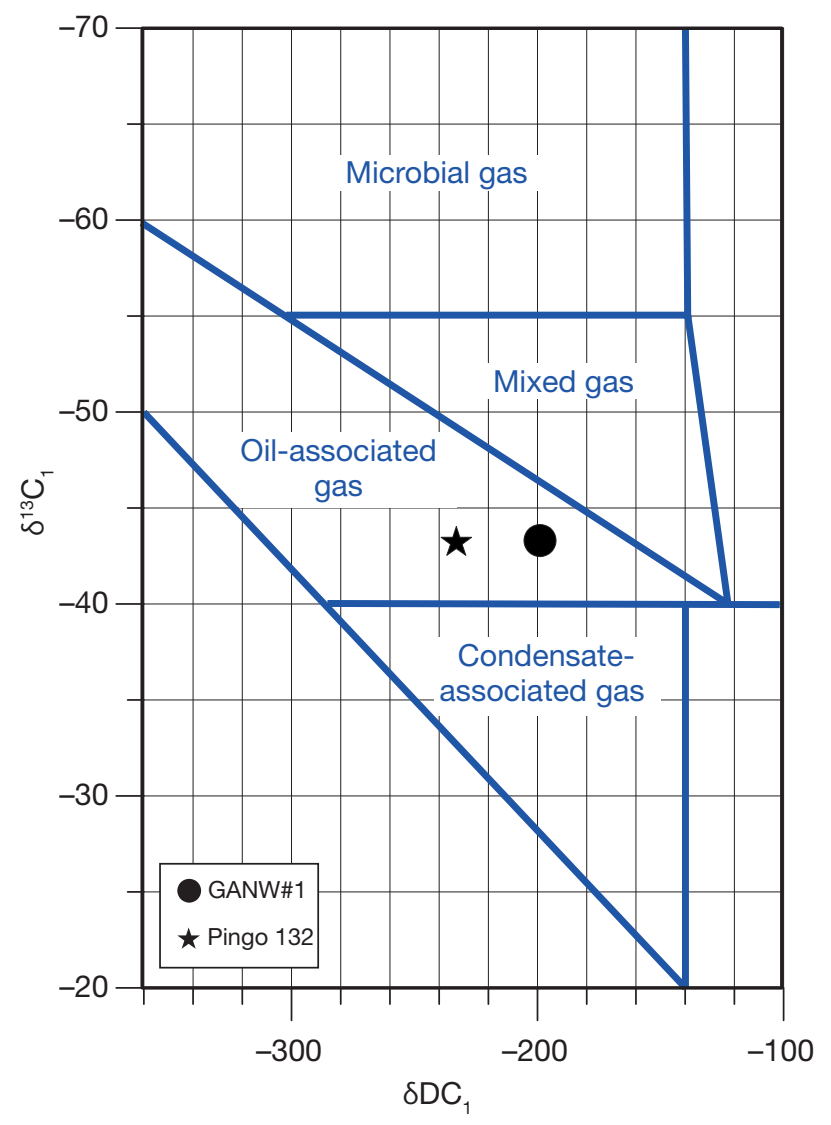

Fig. $6 \delta^{13} \mathrm{C}$ of methane $\left(\boldsymbol{\delta}^{13} \mathbf{C}_{1}\right)$ versus $\delta D$ of methane $\left(\boldsymbol{\delta D C _ { 1 }}\right)$ for GANW\#1 and Pingo 132. Plotted compositional fields (blue lines) are from Jenden and Kaplan (1989). 


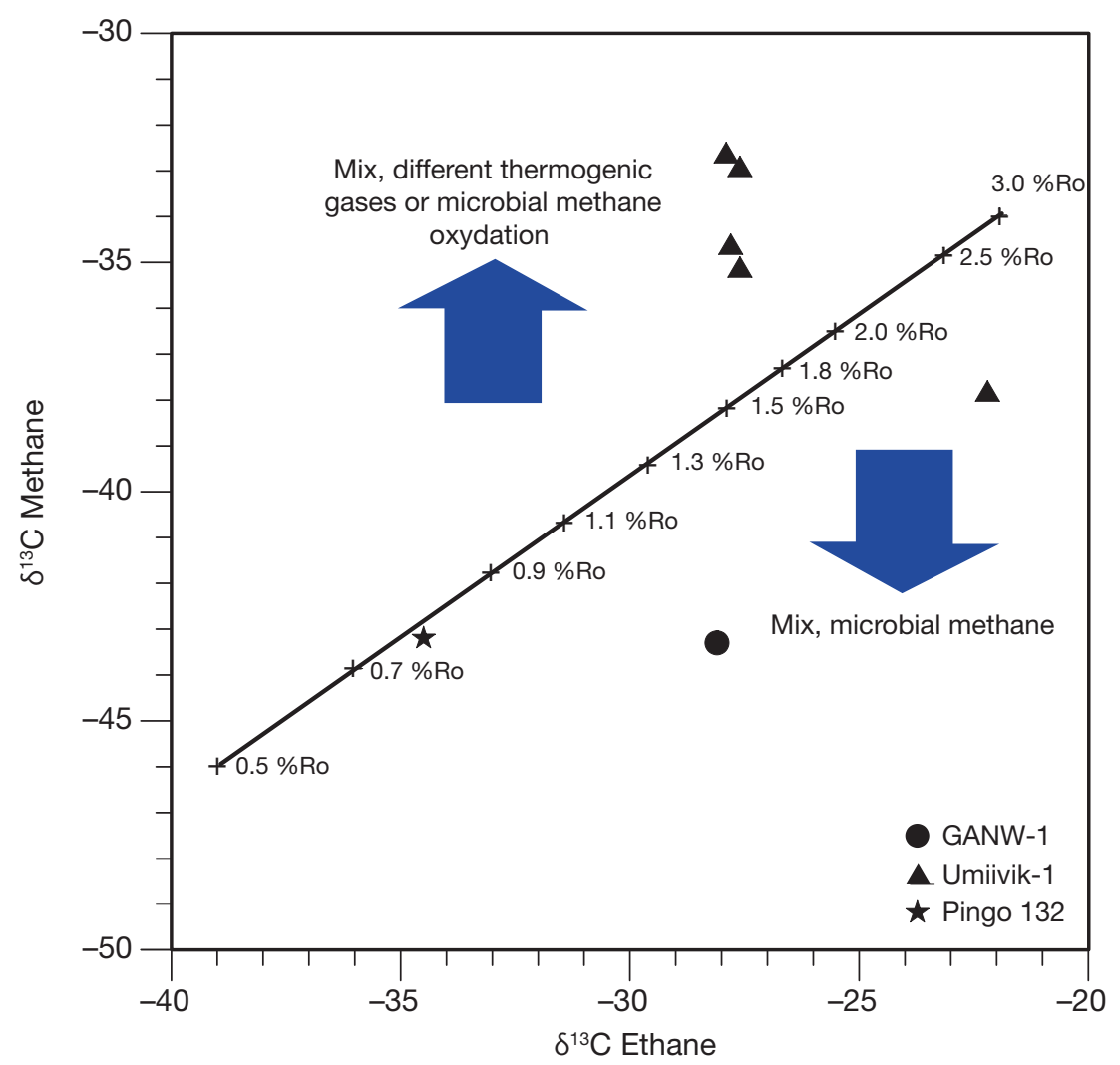

Fig. $7 \delta^{13} \mathrm{C}$ of methane $\left(\boldsymbol{\delta}^{13} \boldsymbol{C}_{1}\right)$ versus $\delta^{13} \mathrm{C}$ of ethane $\left(\boldsymbol{\delta}^{13} \boldsymbol{C}_{2}\right)$ for GANW\#1, Umiivik-1 and Pingo 132. Maturity lines are calculated from Faber (1987) for type II kerogen. $\mathbf{R}_{\mathbf{o}}$ : vitrinite reflectance. and GANE\#1, indicated by bubbles in the drilling fluids. Most notable was the gas flaring of GANE\#1 at a depth of c. $660 \mathrm{~m}$ (see fig. 4 in Christiansen et al. 1996a). Corresponding cores from this drilling depth show oil impregnation with the relatively rare "Eqalulik type" that cannot be correlated to any known source rock (Bojesen-Koefoed et al. 1997a, 1999).

In GANE\#1 (and GANE\#1A), gas was commonly observed in several sandstone intervals (631-641, 684689 and 696-702 m). In GANT\#1, gas was commonly observed in many sandstone intervals between 575 and $775 \mathrm{~m}$. Most of these gases are thermogenic in origin. But their variable composition suggests the presence of both low maturity gases from the penetrated succession and high maturity gases that may have migrated from deeper in the subsurface (Table 1).

\subsection{Umiivik-1, drilled in 1995}

Umiivik-1 (core 439301) was drilled as a $1200 \mathrm{~m}$ deep stratigraphic well by grønArctic Energy for GGU in August to September 1995. The main goal was to test and document a Cenomanian-Turonian source rock (Bate \& Christiansen 1996; Dam et al. 1998). In the deeper part of the well, gas was heard to be escaping the core. Some intervals revealed a white froth on the core surface when it was removed from the core barrel (Bate \& Christiansen 1996).
Twenty-seven core pieces were sealed in cans and analysed for their gas composition (Christiansen et al. 1997b; Dam et al. 1998). Sixteen of these are presented in Table 1 - the remaining nine samples had no detectable amounts of gas. Gas concentrations of the 16 samples were high, with significant amounts of wet gases such as propane, butane and pentane (Table 1). In some deeper parts of the well, concentrations were so high that the sampling cans deformed. Compositions in the deeper part are typical of thermogenic gas associated with oil (Table 1; Figs 5 and 7). Unfortunately, the isotopic composition trend suggests some diffusion after sampling as suggested by Christiansen et al. (1997b). The presence of a postmature oil-prone source rock in the deeper part (below 1100 m) of Umiivik-1 was documented in more detail by Drits et al. (2007).

\subsection{GRO\#3, drilled in 1996}

GRO\#3 was drilled by grønArctic Energy in the summer of 1996, following promising results from previous drilling and seep studies (Christiansen et al. 1997a, 1998).

Cores or sidewall cores were not included in the drilling programme, and the organic geochemical results are based on analysis of cuttings only (Bojesen-Koefoed et al. 1997b; Christiansen et al. 1998). Eight sandstone intervals were drillstem tested to obtain fluid samples, but results were inconclusive. Later, log interpretation 
indicated many intervals with high gas concentrations (Kristensen \& Dam 1997). These petrophysical data are not presented in this review.

\subsection{Vismann mineral exploration, drilled in 2007}

The company Vismann Exploration Inc. drilled two mineral exploration boreholes in the Aaffarsuaq valley, in 2007, based on previously observed geophysical anomalies in the area (Fig. 2). The logistical operation was complex and required construction of a new road into the Aaffarsuaq valley. Both of the wells were suspended due to gas under pressure at depths of 154 and $133 \mathrm{~m}$. Neither of the holes reached bedrock and they only penetrated the Quaternary overburden (glacial tills). Unfortunately, no gas was sampled.

\subsection{Lakes and pingos}

The best opportunity to observe gas seepage in land terrains, like the Nuussuaq Basin, is from lakes, pingos, below newly formed ice or on partly wet mud flats. Pingos are conspicuous mound-like landforms that are common in regions with continuous permafrost. They may have craters resembling those of mud volcanoes (Pissart 1988). Active pingos are formed by periglacial processes, have an ice core of frozen water and often grow over time. Some eventually collapse. Pingos are common in many valleys on Disko, Nuussuaq and Svartenhuk Halvø. Expedition anecdotes of bubbling lakes suggested the presence of gas seepage as early as the 1930s. Early analyses of both gas and water collected in the 1930s and 1940s were first presented in the context of petroleum exploration by Henderson (1969). These early analyses document a significant content of methane and alkaline water associated with gas seepage. Many of the pingos in the region were more systematically studied in the 1990s - most of them were dry. Some occasionally show crater lakes or outlets of spring water under artesian pressure. Sampling of these waters may give information on the composition of water and gases below the permafrost.

Pingo 132 (Fig. 2) north of the Aaffarsuaq river seems to have been rather active and wet over many decades. Note that Henderson (1969) uses the term Qapiortoq kitdleq for the same pingo. Pingo 132 was visited and sampled on several occasions in 1991 and 1992. Snow fans were observed to disappear from Pingo 132 later than on any other southward facing slopes in this part of the Aaffarsuaq valley. On one occasion, a fountain of water under pressure was observed (Fig. 8A). A similar feature was documented in a photo taken on 25 August 1939 by B. Thomsen (see fig. 6 in Henderson 1969).

Looking downstream from the snow fan, which covers part of the pingo, the valley floor is described as being overgrown with algae and other vegetation, suggesting that the outlet has been active over long periods of the year and that the water is rich in nutrients. This remarkable colouration may be a good proxy for remote-sensing studies of other similar outlets in the region.

Elsewhere, gas seepage from the hinterland of Marraat is indicated by the so-called Gassø lake (Fig. 2), depicted in the 1:100 000 geological map of the area (Rosenkrantz et al. 1974) and the official Geodætisk Institut 1:250 000 topographical map from 1980. The lake was visited by Flemming G. Christiansen and Inger Salomonsen on 28 July 1994. The lake surface showed clear evidence of seepage as intense bubbling (Fig. 8B). Analyses of lake water (sampled in cans) indicated a complete dominance of nitrogen (Laier, unpublished data, October 1994; Supplementary File S2), suggesting either long-distance migration of gases that are thermally very mature, or more likely that oxygen had been lost by bacteria in an anoxic environment.

A third and more recent example is from the Marraat area, where a new pingo seems to be actively forming (Figs 2 and $8 C$ ). The normally flat riverbed surface is doming with new fractures in the peaty soil. The underlying ice-core is beginning to be exposed and large bubbles of gas are visible in small ponds nearby, beneath recently formed ice (Fig. 8D). Such features with fractures opening to permafrost below - and possibly with degrading permafrost - may become more common on Nuussuaq in the years to come, especially in areas with active movements.

\subsection{Marine records}

Geophysical data, including conventional seismic data and high-resolution shallow seismic data, indicate that gas could be very common in the sedimentary succession below the seabed of Vaigat (location in Fig. 2). Examples of so-called direct hydrocarbon indicators have been observed offshore in Vaigat, particularly as flat spots but also as gas cloud features (Bojesen-Koefoed et al. 2007).

Geochemistry data of pore waters from gravity cores indicate that gas hydrates may also be present at several places offshore in Disko Bugt and Vaigat (Mikkelsen et al. 2012; Nielsen et al. 2014). This is supported by numerous observations of pockmarks, seabed mud diapirs and change in reflection patterns on geophysical data in the area. Kuijpers et al. (2001) also observed intense degassing from two cores south of Disko. To the best of our knowledge, no gas samples have been analysed.

\subsection{Summary: existing gas observations}

Historical observations of gas seepage in the Nuussuaq Basin are to some degree supported by modern analytical data. Large parts of the Nuussuaq Basin are clearly 

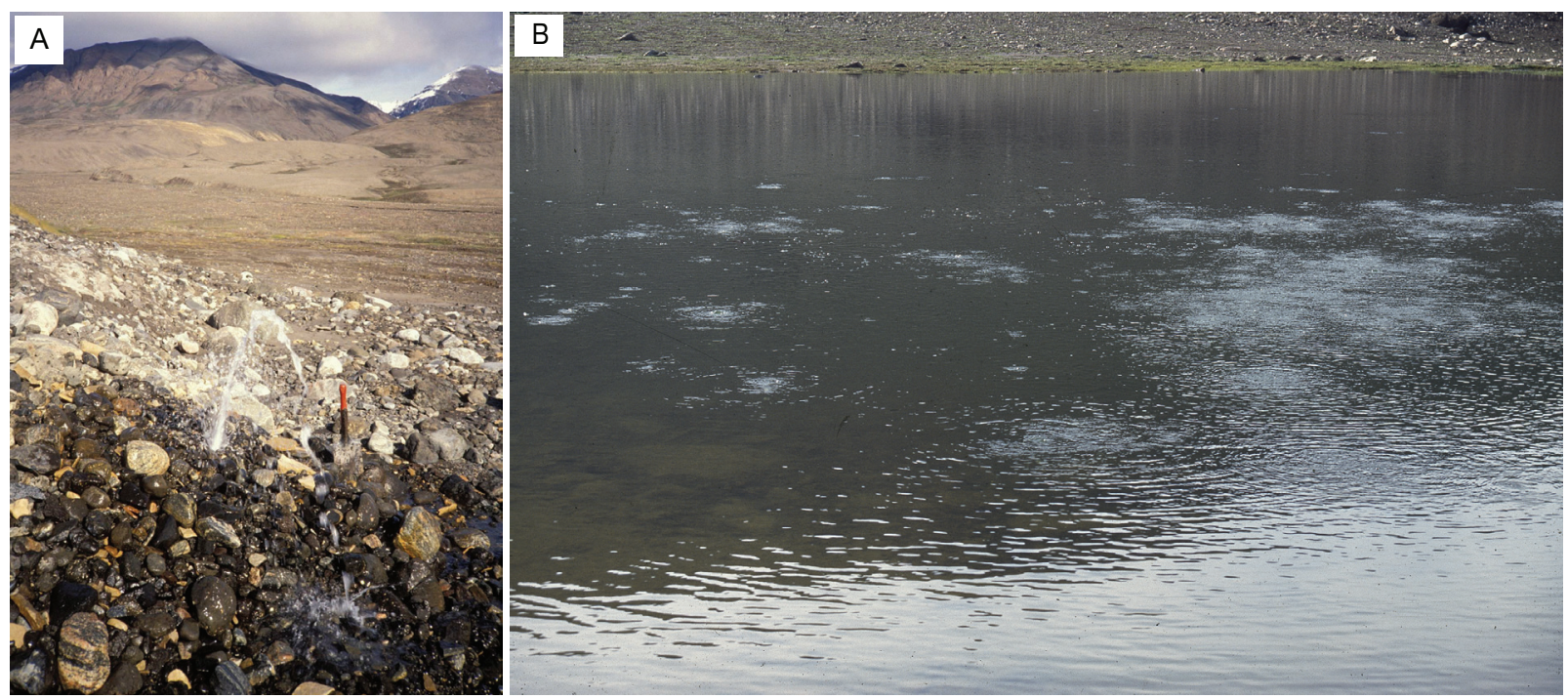

C
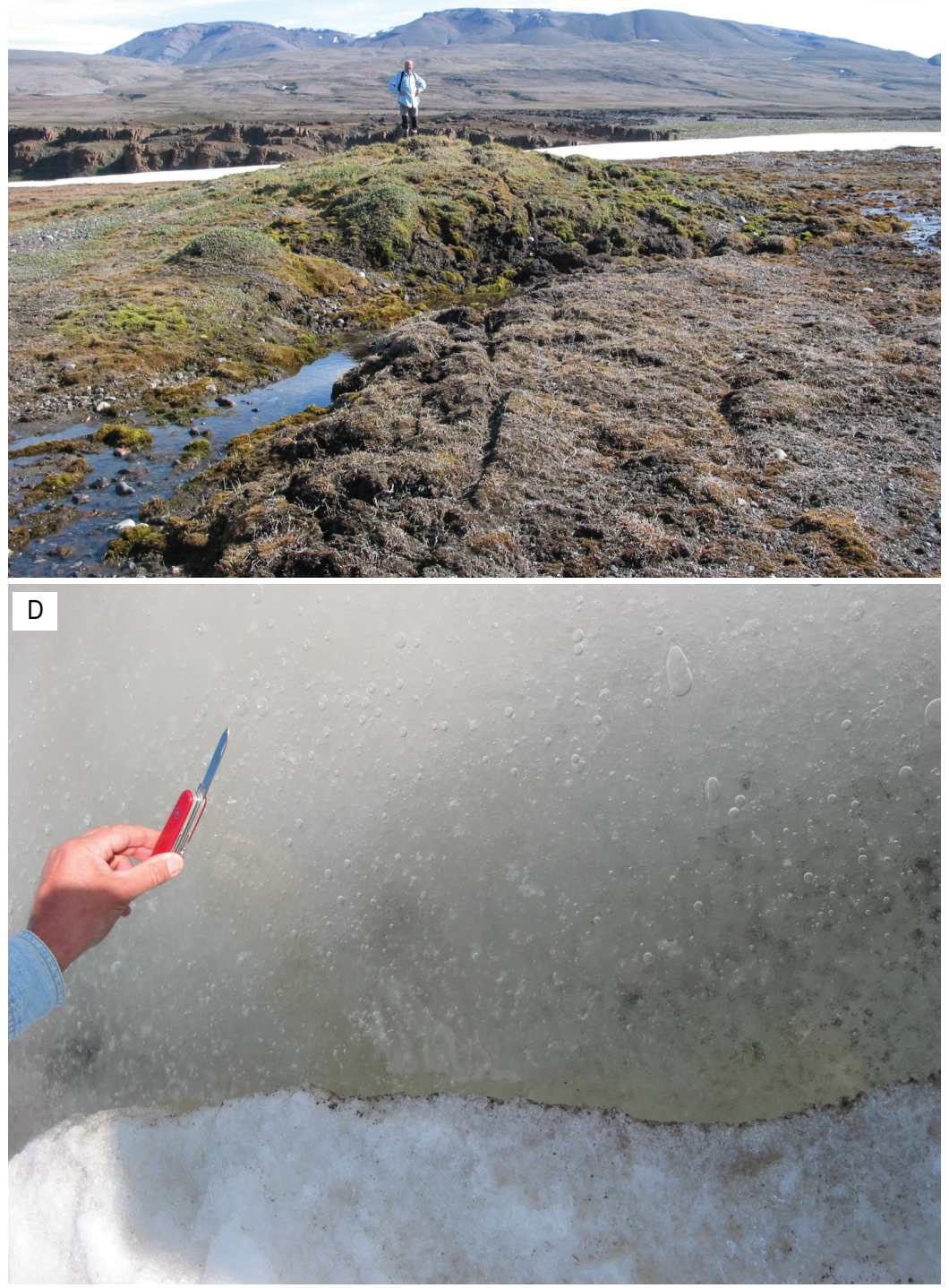

Fig. 8 Features of Pingo 132 in Aaffarsuaq Valley, Gassø lake, and a new pingo near Marraat-1 core. A: Water fountain indicating water with a high gas content under artesian pressure below the permafrost, 17 August 1991. B: Surface of Gassø lake with clear indications of gas seepage, 28 July 1994. C: Doming, soil fracturing and possible formation of a new pingo near Marraat-1, 27 July 2006 (photo: Roy Fitzsimmons). D: Gas trapped under ice in a small pool near Marraat-1, 27 July 2006. 
underlain by a sedimentary succession that contains high concentrations of gas. Although dominated by biogenic gas, gases from surface lakes and pingos show a distinct thermogenic component. The gases from boreholes are mainly thermogenic in origin, and in some cases, their composition suggests an association with oil. These oil-associated gases have a rather low thermal maturity corresponding to the thermal maturity of the sediments penetrated by drilling.

In several cases, examples of thermally high-maturity gases have been recorded. These gases may have migrated from the deeper part of the sedimentary succession or were generated in the vicinity of dykes and sills. Clearly, better systematic sampling techniques, proper handling and storage, and most importantly, rapid analyses using modern instrumentation could provide much more valuable information.

GANT\#1, Pingo 132 and the Vismann mineral exploration holes are all in close proximity to the anticline, suggested by Sørensen et al. (2017) to be a large potential target for future exploration. It is therefore particularly important to get more data on oil and gas seeps from this area.

\section{9 reconnaissance to sample oil and gas seepage}

\subsection{Biomarkers in oil seepage near the Kuugannguaq-Qunnilik Fault zone}

On 26 July 2019, we visited a number of planned drill sites next to the Kuugannguaq-Qunnilik Fault zone in the Aaffarsuaq valley to check for oil seepage (Fig. 2). Hyaloclastites from the deep part of the Vaigat Formation were examined for signs of petroleum staining. The hyaloclastites are from unit 409 of the Nuusap Qaqqarsua Member within the Naujánguit Member of the Vaigat Formation (Fig. 3; see details in Pedersen et al. 2002, 2017). We sampled the hyaloclastites, located c. 340 m.a.s.I., close to the outlet of the Qunnillik canyon (sample site 574305 in Fig. 2), a few hundred metres west of the expected trace of the Kuugannguaq-Qunnillik Fault zone.

We picked out small pieces of a hard, fresh rock with thin carbonate veins and a distinct petroliferous odour for organic geochemical analyses using standard methods (Bojesen-Koefoed et al. 2018).

A sample of rock pieces was lightly crushed and extracted for $4 \mathrm{~h}$ (1 $\mathrm{h}$ immersed in boiling solvent followed by $3 \mathrm{~h}$ of rinsing) using a Soxhtec ${ }^{\mathrm{TM}}$ instrument and a 93+7 vol./vol. dichloromethane + methanol mixture as solvent. The extract was recovered by evaporation over $\mathrm{N}_{2}$ and weighed. A $238 \mathrm{~g}$ sample was extracted to obtain a total yield of $6.2 \mathrm{mg}$ extract, corresponding to c. $26 \mathrm{ppm}$. Asphaltenes were precipitated by the addition of 40 -fold excess $n$-pentane. Asphaltenes were recovered by centrifugation and rinsed through several stages with $n$-pentane. Asphaltenes account for $27.4 \%$ by weight of the total. Maltene (i.e. asphaltene-free) fractions were separated in saturated hydrocarbons, aromatic hydrocarbons and polar fractions by medium-pressure liquid chromatography using a procedure modified from Radke et al. (1980). The maltene fraction is dominated by polar NSO compounds (Table 2 ).

The saturated hydrocarbon fraction was analysed by gas chromatography-flame ionization detection $\left(\mathrm{GC}_{\mathrm{FID}}\right.$ ) using a Shimadzu gas chromatograph, furnished with a 30-m WCOT ZB-1 capillary column. Biomarker analysis was carried out by gas chromatography-mass spectrometry (GC-MS) using an Agilent $6890 \mathrm{~N}$ gas chromatograph, fitted with a $30 \mathrm{~m}$ WCOT ZB-5 capillary column, coupled to a Waters (Micromass) Quattro Micro GC tandem quadrupole-hexapole-quadrupole MS. The instrument was run in both Selective Ion Monitoring mode (GC-MS $\mathrm{MIM}_{\mathrm{M}}$ ) and GC-MS-MS parent-daughter mode. The sample was run several times using methods designed to optimise the representation of different compounds.

Gas chromatographic data on the saturated hydrocarbon fraction show a strongly front-end evaporated distribution of $n$-alkanes, a high proportion of longchain components (Fig. 9A) and no unresolved complex mixture, suggesting limited biodegradation (Fig. 9A). Front-end losses of short-chain components make calculation of standard ratios futile, including the pristane/ phytane ratio.

The concentrations of tricylic terpanes (Fig. 9B) are relatively low, and their distribution partially obscured by the presence of abundant unknown components in the same range, probably various other tri- and tetracyclic components. Pentacyclic triterpanes show a series of hopanes ranging from C27 to C35, including notable proportions of 28.30-bisnorhopane (H28, Fig. 9C) and oleanane (O, Fig. 9C), plus trace amounts of bicadinanes and taraxastane (not shown). Extended 28-bisnorhopanes are absent, as are nor/bisnorlupanes. The bishomohopane isomerisation ratio has reached equilibrium

Table 2 Maltene fraction extracted from oil-stained hyaloclastics (sample site 574305, Fig. 2) in the Affarsuaq valley, Nuussuaq Basin

\begin{tabular}{lccc}
\hline Sample & Saturated hydrocarbons (wt.\%) & Aromatic hydrocarbons (wt.\%) & Polar compounds (wt.\%) \\
\hline 574305 & 10.0 & 2.5 & 87.5 \\
\hline
\end{tabular}

NSO: nitrogen, sulphur, oxygen. 

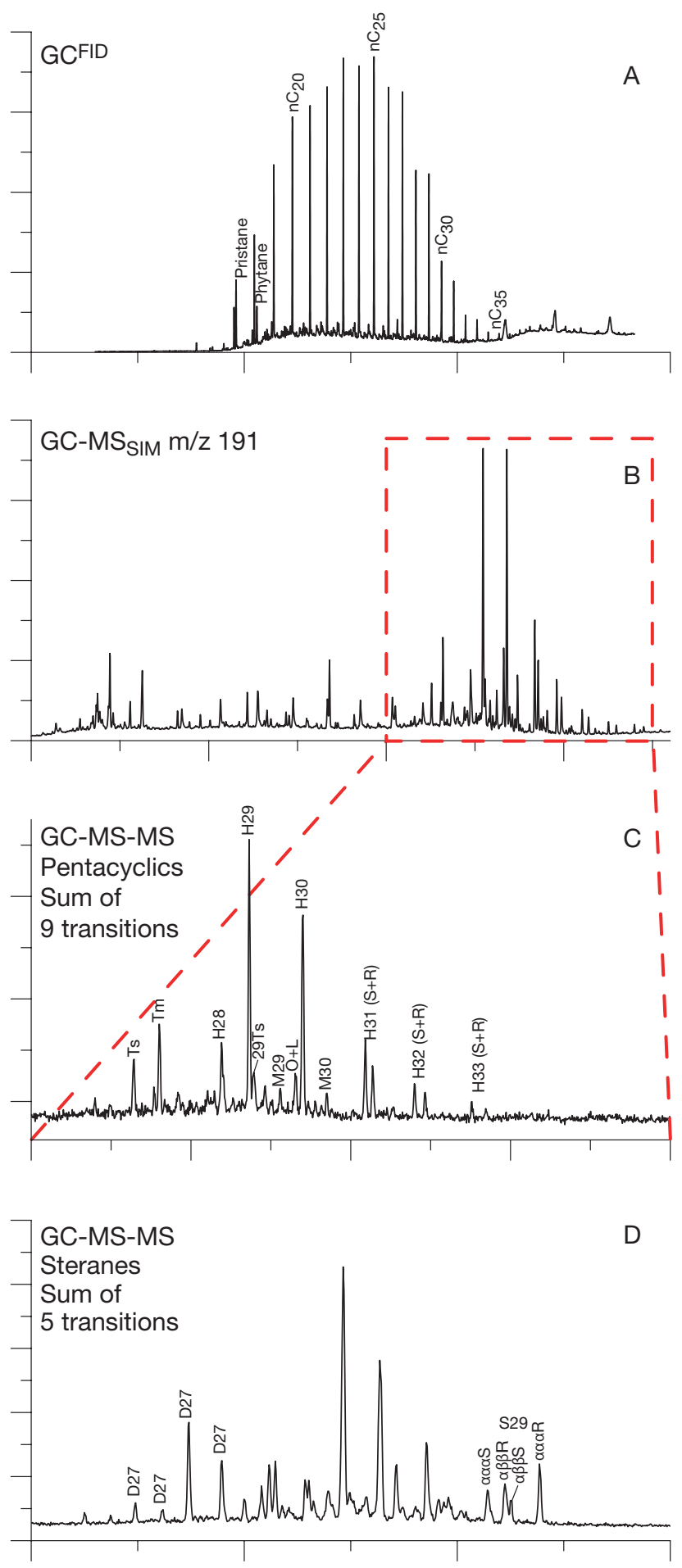

Fig. $9 \mathrm{GC}_{\mathrm{FID}}$ and GC-MS-MS data (time vs. signal) for a sample of oil-stained hyaloclastics (sample site 574305; Fig. 2), Aaffarsuaq Valley, Nuussuaq Basin. A: $\mathrm{GC}_{\mathrm{FID}}$ data. B: GC-MS $\mathrm{SIM}_{\mathrm{M}}$ for $\mathrm{m} / \mathrm{z}$ 191. C: GCMS-MS of pentacyclics. Sum of nine transitions. D: GC-MS-MS of steranes. Sum of five transitions. Symbols are as follows: $\mathbf{n C}_{\boldsymbol{x}}$ : normal alkanes ( $x=$ carbon number); pristane: $\mathrm{C}_{19}$ acyclic isoprenoid; phytane: $C_{20}$ acyclic isoprenoid; Ts: $18 \alpha$-trisnorneohopane; Tm: 17 $\alpha$-trisnorhopane; H28: 28,30-bisnorhopane; H29: norhopane; 29ts: $C_{29}$ neohopane; M29: normoretane; $\mathbf{O + L}$ : coelution of oleanane + lupane; H30: hopane; M30: moretane; HXX (S+R): homohopanes, doublets $22 \mathrm{~S}$ and $22 \mathrm{R}$ isomers; $\mathrm{XX}=$ carbon number; $\mathbf{D 2 7}$ : C27 diasteranes; S29: C29 regular steranes; aaas: regular sterane $\alpha \alpha \alpha$ 20S isomer; $\boldsymbol{\alpha} \beta \boldsymbol{\beta} \boldsymbol{S S}$ : regular sterane $\alpha \beta \beta 20 \mathrm{~S}$ isomer; $\boldsymbol{\alpha} \beta \boldsymbol{\beta} \mathbf{R}$ : regular sterane $\alpha \beta \beta$ 20R isomer; aaaR: regular sterane $\alpha \alpha \alpha$ 20R isomer. at $0.61(\mathrm{H} 32 \mathrm{~S} /(\mathrm{S}+\mathrm{R})$, Table 3, Fig. 9C). The sample shows high concentrations of aromatic diterpanes which are a common feature of terrestrial oils found on Nuussuaq, moderate concentrations of phenanthrene and methylphenanthrene (not shown), and the presence of di- and triaromatic oleanane. The sterane distribution is strongly dominated by C29 moieties and shows very high proportions of diasteranes (Fig. 9D). C30 desmethyl steranes are absent, but C26-steranes are relatively prominent and allow calculation of a nordiacholestane ratio of 0.37 (Holba et al. 1998). C29-sterane 20S/(20S+20R) and $\alpha \beta \beta /$ $(\alpha \alpha \alpha+\alpha \beta \beta)$ isomerisation ratios are both below equilibrium at 0.43 and 0.42 , respectively (Table 3, Fig. 9D).

Sample 574305 can be classified as a "Niaqornarsuk type" oil with some notable deviations, according to its biological-marker characteristics as first defined by Bojesen-Koefoed et al. (1999; Table 4). A few parameters fall outside the established range for this oil type, notably the relative abundance of diasteranes and 28,30-bisnorhopane. However, the following diagnostic criteria are fulfilled:

1. Appreciable concentrations of 28,30-bisnorhopane and absence of extended 28-norhopanes (Table 4).

2. Presence of oleanane (perhaps coeluting with small amounts of lupane, see Nytoft et al. [2020]), with no or negligible concentrations of nor/bisnorlupanes (Table 4, Fig. 9C).

3. Strong predominance of C29-steranes and absence of C30 desmethyl steranes (Table 4, Fig. 9D).

The aromatic fingerprint, in particular the moderate concentrations of phenanthrene and methylphenanthrene, further supports the identification of sample 574305 as "Niaqornarsuk type" oil.

The characteristic features of the "Niaqornarsuk type" oil were originally defined using only GC-MS( ${ }_{\text {SIM }}$ ) data, which are inferior to modern GC-MS-MS. Sterane data based on GC-MS( ${ }_{S I M}$ ) suffer from coelution problems, which often cause misleadingly low ratios of diasteranes to regular steranes.

The Niaqornaarsuk oil type has been linked to Campanian-age source rocks, based on the geochemical correlation to Campanian-age shales of the GANT\#1 borehole (Bojesen-Koefoed et al. 1999), which are perfectly conformable with a nordiacholestane ratio of 0.37 (Holba et al. 1998). The sample was collected at least 10 $\mathrm{km}$ from any other known occurrence of surface seepage near the Kuugannguaq-Qunnillik Fault zone, which is encouraging for future exploration. The presence of a Niaqornaarsuk oil type at a considerable distance from the only hitherto known occurrences of this oil type further supports the presumed existence of Campanian age deposits developed in source-rock facies in the region. 
Table 3 Key geochemistry parameters for sample 574305

\begin{tabular}{|c|c|c|c|c|c|c|c|c|}
\hline Sample & $\begin{array}{c}\text { C19-26 } \\
\text { Tricyclics/ } \\
\text { hopane }\end{array}$ & $\begin{array}{c}\text { C23 } \\
\text { Tricyclic/ } \\
\text { hopane }\end{array}$ & $\begin{array}{l}\text { C25/C26 } \\
\text { Tricyclics }\end{array}$ & $\begin{array}{c}\text { C24 } \\
\text { Tetracylic/ } \\
\text { hopane }\end{array}$ & $\mathrm{H} 32 \mathrm{~S} /(\mathrm{S}+\mathrm{R})$ & $\mathrm{Ts} /(\mathrm{Ts}+\mathrm{Tm})$ & $\begin{array}{c}S 29 \\
S /(S+R)\end{array}$ & $\begin{array}{c}\mathrm{s} 29 \alpha \beta \beta / \\
(a \alpha a+\alpha \beta \beta)\end{array}$ \\
\hline 574305 & 0.09 & 0.01 & 0.83 & 0.01 & 0.61 & 0.41 & 0.43 & 0.42 \\
\hline
\end{tabular}

H32 S/(S+R): bishomohopane isomerisation ratio; TS/(Ts + Tm): 18 $\alpha$-trisnorneohopane/(18 $\alpha$-trisnorheohopane + $17 \alpha$-trisnorhopane); S29 S/(S+R): C29 sterane $20 \mathrm{~S} /(20 \mathrm{~S}+20 \mathrm{R})$ isomerisation ratio; $S 29 \alpha \beta \beta /(\alpha \alpha \alpha+\alpha \beta \beta)$ : C29 sterane $\alpha \beta \beta /(\alpha \alpha \alpha+\alpha \beta \beta)$ isomerisation ratio.

Table 4 Comparison of sample 574305 with the Niaqornaarsuk oil type (Bojesen-Koefoed et al. 1999)

\begin{tabular}{llcccccccc}
\hline Sample & & $\mathrm{H} 28 / \mathrm{H} 29$ & $\mathrm{H} 29 / \mathrm{H} 30$ & $\mathrm{O} /(\mathrm{O}+\mathrm{H} 30)$ & $\mathrm{D} 27 / \mathrm{RS} 27$ & $\mathrm{RS} 27 / \mathrm{RS} 29$ & $\mathrm{~S} 27 \%$ & $\mathrm{~S} 28 \%$ & $\mathrm{~S} 29 \%$ \\
\hline 574305 & & 0.31 & 1.14 & 0.18 & 4.0 & 0.32 & 19 & 21 & 60 \\
Niaqornaarsuk oil type & Mean & 0.17 & 0.92 & 0.06 & 0.87 & 0.32 & 20 & 14 & 65 \\
& Minimum & 0.13 & 0.81 & 0.04 & 0.73 & 0.20 & 15 & 12 & 57 \\
& Maximum & 0.23 & 1.02 & 0.10 & 1.19 & 0.47 & 27 & 17 & 73 \\
\hline
\end{tabular}

H28/H29: 28,30-bisnorhopane to norhopane ratio; $\mathrm{H} 29 / \mathrm{H} 30$ : norhopane to hopane ratio; $\mathrm{O} /(\mathrm{O}+\mathrm{H} 30)$ : oleanane to oleanane + hopane ratio D27/ RS27: C27 diasterane to C27 regular sterane ratio; RS27/RS29: C27 to C29 ratio of regular steranes; S27\%, S28\%, S29\%: relative distribution of regular steranes.

\subsection{Gas seepage in Aaffarsuaq Valley}

\subsubsection{Remote-sensing analysis of Pingo 132}

On 26 July 2019, Pingo 132 in the Aaffarsuaq valley, central Nuussuaq, was visited to check for mud extrusion and gas seepage (Fig. 2). Although Pingo 132 is periglacial in origin, it resembles typical mud volcanos from classical petroliferous basins or geothermal fields with mud overflow (see Etiope 2015; Mazzini \& Etiope 2017; Mazzini et al. 2011).

Today, there is evidence of recent mud extrusion in the area. The mud cropping out is pale in colour, has rather steep sides and many irregular fractures and erosional features that are not likely to survive more than a few winters. There is little to no vegetation on the extruded mudstone, which is in contrast to the older parts of the pingo and surrounding valley floor. The actual mudstone contains numerous clasts of rounded basements boulders, some Cretaceous Atane Formation sandstone lithologies and a few volcanic rock types - all typical of the Quaternary tills in the Aaffarsuaq valley (Fig. 10).

High-resolution satellite images provide good possibilities for detecting surface movements of the pingo and measuring slow displacement rates of centimetres to metres per year. Using Differential Synthetic Aperture Radar (SAR) interferometry (DInSAR; Rosen et al. 2000) to plot the phase differences between two or more satellite SAR images allows us to detect movement in the direction of line-of-sight of a few millimetres and helps characterise the dynamics of terrain uplift. Combining the two complementary techniques overcomes the limitations of using just one of these methods.

To visually identify the changes in the shape of Pingo 132 and outcropping mud over time, we used optical four-band PlanetScope time-series with $5 \mathrm{~m}$ spatial

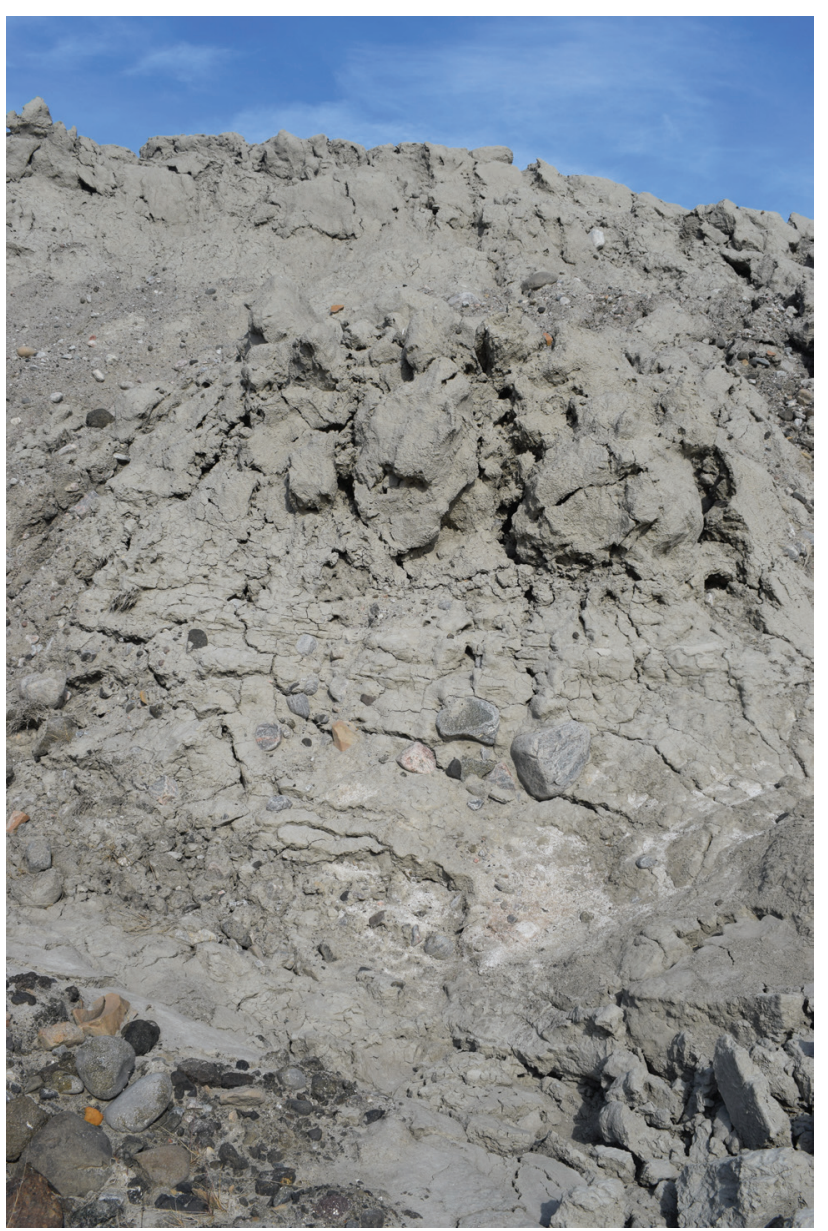

Fig. 10 Extruding muds from the side of Pingo 132. Note the many rounded basements boulders in the mud. Height of section c. 3 m. Photo taken on 26 July 2019.

resolution between 2017 and 2019 (Fig. 11A). The Normalized Difference Vegetation Index (NDVI) is calculated from the same dataset (Fig. 11B) to enhance the 

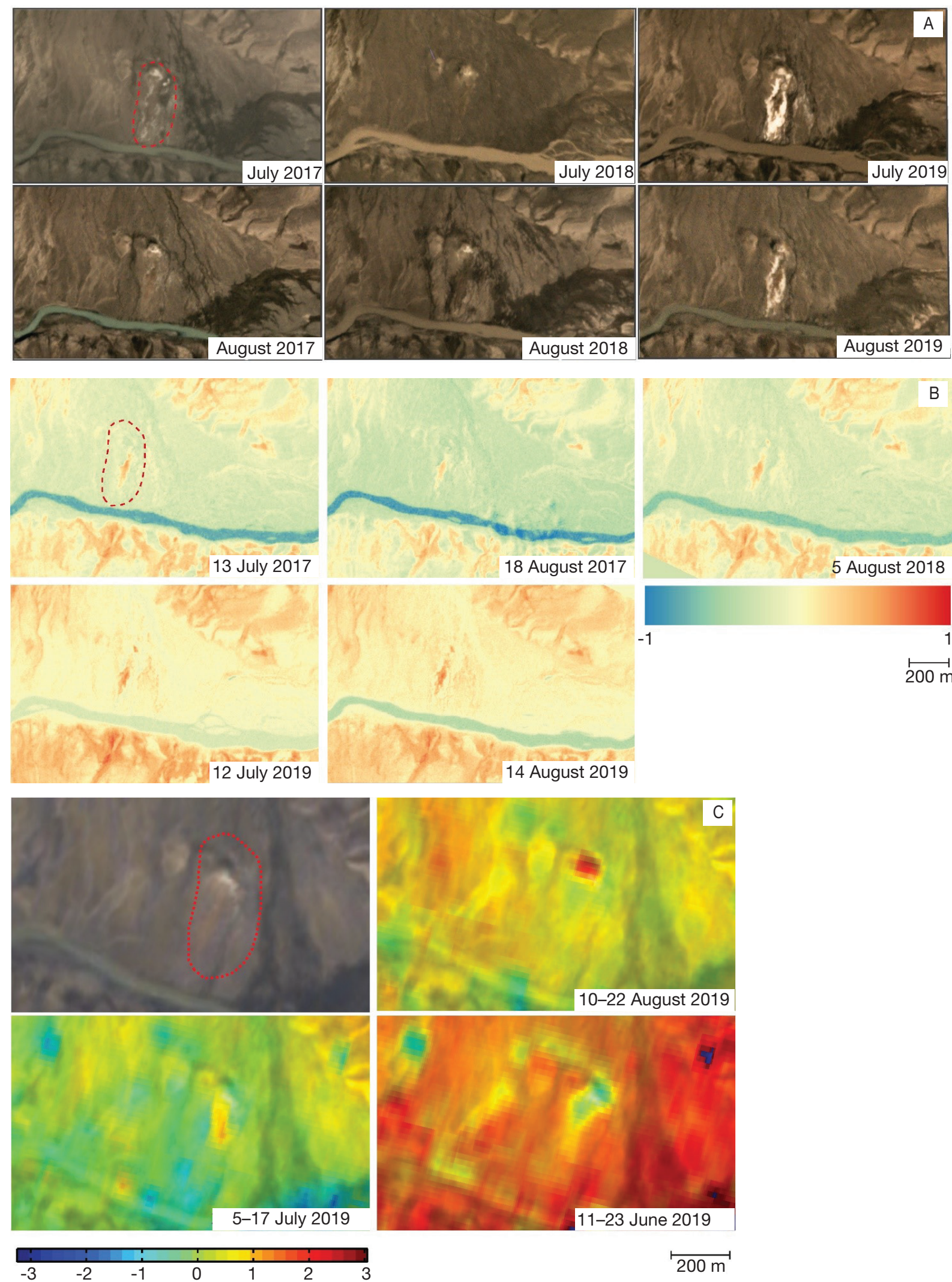

$200 \mathrm{~m}$

Fig. 11 Remote-sensing images and analysis of Pingo 132, Affarsuaqq valley. Red-dashed lines indicate the location of Pingo 132. A: Optical four-band PlanetScope data with $5 \mathrm{~m}$ spatial resolution for July and August 2017-2019. B: Normalized Vegetation Index (NDVI) for July and August 2017 and 2019. Negative values of NDVI correspond to water. Values close to zero (-0.1 to 0.1) generally correspond to barren areas of rock, sand or snow. Low positive values (0.2-0.4) represent shrubs, while high values (approaching 1 ) indicate green vegetation. C:Close-up of Pingo 132. Selected differential interferograms (wrapped interferometric phase) from track 175. Upper row: 10 August 2019-22 August 2019 (temporal baseline: 12 days; normal baseline: -0.06 m). Lower row: 5 July 2019-17 July 2019 (temporal baseline: 6 days; normal baseline: $15.68 \mathrm{~m}$ ) and 11 June 2019-23 June 2019 (temporal baseline: 6 days; normal baseline: $5.46 \mathrm{~m}$ ). 
interpretation of the identified patterns and to measure the concentration of green vegetation. Two Sentinel-1 tracks (i.e. 171 descending and track 90 ascending) cover the same area. Differential SAR Interferometry was carried out for the descending track between 11 June and 3 September 2019 using the Arctic digital elevation model (Porter et al. 2018). The interferograms were unwrapped, and the deformational rates are reported as the satellite line-of-sight rates projected onto the steepest slope. The results indicate significant vertical movements in both summer and winter, suggesting "uplift" rates of $c$. $1 \mathrm{~cm}$ every 12 days, probably related to mud accumuIation (Fig. 11C). Furthermore, seasonal variation in the
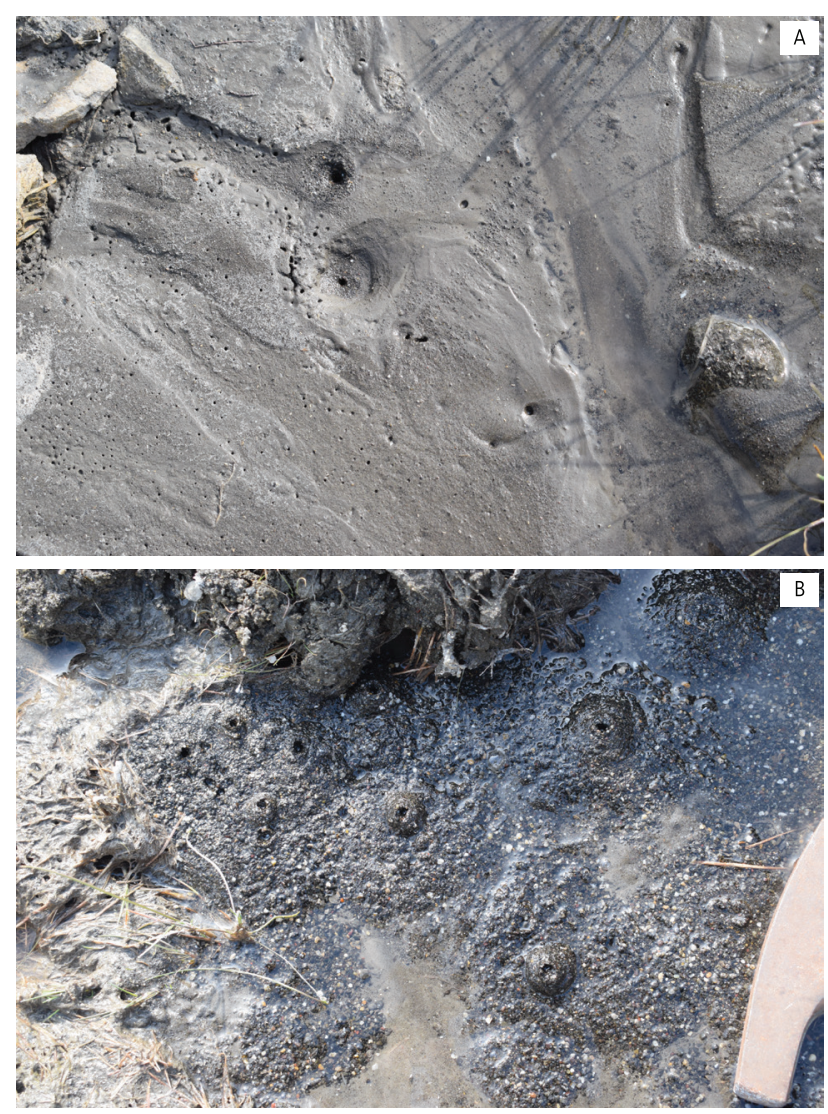

Fig. 12 Gas seepage from Pingo 132. A: Gas escape structures on recently dried-out mud flat on the southern side of Pingo 132, 26 July 2019. Size is c. $20 \times 30 \mathrm{~cm}$. B: Centimetre-scale mounds formed by gas seepage at Pingo 132, 26 July 2019. Hammerhead for scale. uplift rate seen in the DInSAR data matches the seasonal pattern observed in the optical data. It seems that most of the observed mud extrusion took place in the summer of 2017.

\subsubsection{Geochemistry of gas seepage}

The present water outlet is on the lower, south side of the pingo. It is associated with fractures in the soil and peat and small ponds with bubbling gas (see videos in Supplementary Files S4 and S5). Some of the partly dry mudflats show gas-escape vents (Fig. 12A). The sandier material displays a crater-like feature, a few centimetres in size (Fig. 12B).

A gas sample was taken in a plastic bottle where gas displaced the outlet water, kept cool and analysed within a week for $\mathrm{CH}_{4}$ and $\mathrm{C}_{2} \mathrm{H}_{6}$ by standard gas chromatography (Christiansen et al. 1997b). The sample was stored and later analysed for stable carbon and hydrogen isotopes by Martin Krüger at Bundesanstalt für Geowissenschaften und Rohstoffe in Hannover (for methods, see Blumenberg et al. 2016). The seeping gas is mainly composed of methane with a small amount of ethane (Table 5). The carbon isotope composition of methane and ethane using standard classification plots suggests a thermogenic origin with a relatively low thermal maturity (Figs 5-7).

\subsubsection{Geochemistry of water associated with gas accumulation or seepage}

Geochemistry of formation water associated with oil and gas accumulations or related to oil and gas seepage may provide important additional information on the migration and degradation history. Water under pressure has been recorded in a few places on Nuussuaq, both in the Marraat-1 and GANK\#1 wells and in some pingos. Some historical data were published by Henderson (1969), and additional data from the early nineties were compiled and reported by Christiansen et al. (1995b). These are presented in Table 5 along with new data for Pingo 132.

The formation fluids from Marraat- 1 have a higher salinity than seawater and a very high $\mathrm{Ca} / \mathrm{Mg}$ ratio suggesting a deep brine origin (Table 6). There is some variation between different levels, suggesting that the

Table 5 Geochemistry of gas escaping from Pingo 132 sampled in 1991, 1992 and 2019

\begin{tabular}{|c|c|c|c|c|c|c|c|c|}
\hline Sample number & Date & $\mathrm{CH}_{4}\left(\mathrm{C}_{1}\right)(\mathrm{ppm})$ & $\mathrm{C}_{2} \mathrm{H}_{6}\left(\mathrm{C}_{2}\right)(\mathrm{ppm})$ & $\delta^{13} C_{1}(\% 0)$ & $\delta^{13} C_{2}(\% 0)$ & $\delta D C_{1}(\% 0)$ & Wetness & Data sources \\
\hline 358472 & 17 August 1991 & 723000 & 530 & -45.8 & n.a. & n.a. & 1364 & Laier 1994 \\
\hline 400843 & 14 July 1992 & 468000 & n.d. & -40.4 & n.a. & n.a. & n.d. & Laier 1994 \\
\hline 400844 & 14 July 1992 & 81800 & 790 & -38.1 & n.a. & n.a. & 1035 & Laier 1994 \\
\hline 400894 & 14 August 1992 & 355000 & 175 & -43.4 & n.a. & n.a. & 2028 & Laier 1994 \\
\hline 547303 & 26 July 2019 & 239000 & 164 & -43.2 & -34.5 & -233 & 1460 & This study \\
\hline
\end{tabular}

n.a.: not analysed; n.d.: not determined. Wetness: C1/(C2 + C3). C3 not present in any samples. 
Table 6 Geochemistry of water samples from Pingo 132 and nearby formation water, seawater and river water

\begin{tabular}{|c|c|c|c|c|c|c|c|c|c|c|c|c|c|c|}
\hline Sample & Location & Type & $\mathrm{pH}$ & Alk & $\begin{array}{c}\mathrm{Cl} \\
(\mathrm{mg} / \mathrm{l})\end{array}$ & $\begin{array}{c}\mathrm{SO}_{4} \\
(\mathrm{mg} / \mathrm{l})\end{array}$ & $\begin{array}{c}\mathrm{Na} \\
(\mathrm{mg} / \mathrm{l})\end{array}$ & $\begin{array}{c}\mathrm{K} \\
(\mathrm{mg} / \mathrm{l})\end{array}$ & $\begin{array}{c}\mathrm{Ca} \\
(\mathrm{mg} / \mathrm{l})\end{array}$ & $\mathrm{Mg}$ & $\mathrm{Cl} / \mathrm{SO}_{4}$ & $\mathrm{Na} / \mathrm{K}$ & $\mathrm{Ca} / \mathrm{Mg}$ & $\begin{array}{l}\text { Data } \\
\text { sources }\end{array}$ \\
\hline 358472 & Pingo 132 & Fountain water & 8.78 & 46.6 & 256 & 200 & 1135 & 9.48 & 3.68 & 86 & 1.28 & $119 . .7$ & 0.04 & $\begin{array}{l}\text { Laier 1994; } \\
\text { Christiansen } \\
\text { et al. 1995b }\end{array}$ \\
\hline 400843 & Pingo 132 & Fountain water & 8.97 & 42.6 & 248 & 178 & 1110 & 9.74 & 1.68 & 68.5 & 1.39 & 114.0 & 0.02 & $\begin{array}{l}\text { Laier 1994; } \\
\text { Christiansen } \\
\text { et al. 1995b }\end{array}$ \\
\hline 400844 & Pingo 132 & Fountain water & 8.97 & 29.7 & 53.1 & 177 & 750 & 6.72 & 2.46 & 54.5 & 0.30 & 111.6 & 0.05 & $\begin{array}{l}\text { Laier 1994; } \\
\text { Christiansen } \\
\text { et al. 1995b }\end{array}$ \\
\hline 400894 & Pingo 132 & Fountain water & 8.78 & 44.8 & 258 & 180 & 1140 & 9.28 & 2.63 & 76.5 & 1.43 & 122.8 & 0.03 & $\begin{array}{l}\text { Laier 1994; } \\
\text { Christiansen } \\
\text { et al. 1995b }\end{array}$ \\
\hline 547303 & Pingo 132 & Fountain water & 7.87 & 3.17 & 19.9 & 2.16 & 69.6 & 1.52 & 4.30 & 5.71 & 9.2 & 45.7 & 0.75 & This study \\
\hline 408011 & Marraat-1 & $\begin{array}{l}\text { Formation } \\
\text { water } \\
\text { (41 m depth) }\end{array}$ & 7.42 & 0.92 & 29200 & 1484 & 9650 & 188 & 6740 & 790 & 19.68 & 51.3 & 8.53 & $\begin{array}{l}\text { Laier 1994; } \\
\text { Christiansen } \\
\text { et al. 1995b }\end{array}$ \\
\hline 408021 & Marraat-1 & $\begin{array}{l}\text { Formation } \\
\text { water } \\
\text { (82 m depth) }\end{array}$ & 7.41 & 0.58 & 29600 & 1252 & 8180 & 126 & 8560 & 630 & 23.64 & 64.9 & 13.59 & $\begin{array}{l}\text { Laier 1994; } \\
\text { Christiansen } \\
\text { et al. 1995b }\end{array}$ \\
\hline 408035 & Marraat-1 & $\begin{array}{l}\text { Water under } \\
\text { pressure } \\
\text { (346 m depth) }\end{array}$ & 7.15 & 0.43 & 26500 & 1276 & 6780 & 167 & 8160 & 630 & 20.77 & 40.6 & 12.95 & $\begin{array}{l}\text { Laier 1994; } \\
\text { Christiansen } \\
\text { et al. 1995b }\end{array}$ \\
\hline 408036 & $\begin{array}{l}\text { Vaigat, } \\
\text { Maraat-1 }\end{array}$ & Sea water & 7.94 & 2.10 & 19500 & 2340 & 10500 & 402 & 430 & 1230 & 8.33 & 25.2 & 0.36 & $\begin{array}{l}\text { Laier 1994; } \\
\text { Christiansen } \\
\text { et al. 1995b }\end{array}$ \\
\hline 380132 & $\begin{array}{l}\text { Vaigat, } \\
\text { GANW\#1 }\end{array}$ & Sea water & 7.94 & 2.20 & 18930 & 2033 & 8797 & 403 & 412 & 1217 & 9.31 & 21.8 & 0.34 & $\begin{array}{l}\text { Laier 1994; } \\
\text { Christiansen } \\
\text { et al. 1995b }\end{array}$ \\
\hline 380133 & GANW\#1 & River water & 8.20 & 3.20 & 13 & 11 & 20.7 & 0.29 & 32.4 & 17.5 & 1.18 & 71.4 & 1.85 & $\begin{array}{l}\text { Laier 1994; } \\
\text { Christiansen } \\
\text { et al. 1995b }\end{array}$ \\
\hline
\end{tabular}

Alk: alkalinity.

different volcanic lithologies and their content of zeolites could affect composition.

Pingo 132 is less saline than Marraat-1 (Table 6). It should be noted that in Pingo 132, there is an increased salinity compared to river water, and with high $\mathrm{Na} / \mathrm{K}$ ratios, low $\mathrm{Ca} / \mathrm{Mg}$ ratios and low $\mathrm{Cl} / \mathrm{SO}_{4}$ ratios (Table 6). The 1991 and 1992 samples (fountain water only) have a rather consistent composition through time and a slightly enriched $\mathrm{pH}$ between 8.78 and 8.97 (average: 8.89) compared to the river, sea and formation waters and a high alkalinity (Table 6). The 2019 sample was collected in a small pool and seems to be dominated by surface water from melting snow.

\section{Implications for exploration and recommendation for future studies}

The 2019 and previously documented gas data and 2019 oil seep data from Nuussuaq support an exploration model for the anticlinal structures mapped by Sørensen et al. (2017). Petroleum extracted from an oil-stained hyaloclastite sample, collected in the Aaffarsuaq valley, in 2019 represents a facies variety of the "Niaqornaarsuk type" sensu Bojesen-Koefoed et al. (1999). The presence of a "Niaqornaarsuk type" oil $10 \mathrm{~km}$ from other known occurrences of this oil type further supports the presumed existence of Campanian age deposits developed in source-rock facies in the region. Importantly, we observed no sign of mixing with the "Marraat type," suggesting that the Marraat source rock disappears somewhere between GANK\#1 and the KuugannguaqQunnilik Fault zone, or that the source rock, if present, is thermally immature. Furthermore, numerous examples of gas occur within a few kilometres on either side of the mapped anticline and along possible migration pathways. These gases have a thermogenic fingerprint and suggest a possible origin from oil-prone source rocks with a relatively low thermal maturity.

Further geological and structural mapping using 3D photogrammetry combined with geophysical data would be an ideal approach to develop the exploration model in the region. Moreover, future studies should 
systematically sample oil traces along faults and fractures and focus on rock types with carbonate-filled veins that often host fluid inclusions, to elucidate the vertical and lateral distribution of the active petroleum systems in the Nuussuaq Basin. In some ways, this compares to the practice of traditional onshore exploration in areas like California and Texas more than a hundred years ago, where targets were often defined by a combination of surface structures and seeps. This rule of thumb is still valid in many onshore areas around the world, but knowledge of the distinct oil types can guide exploration even more efficiently.

Systematic mapping, sampling and characterisation of gas seepage from pingos, lakes and thawing permafrost could be similarly important in the future. Professional sampling tools for both onshore and offshore activities, including transport and storage of samples under cool conditions, are important, and samples should be analysed as soon as possible to reduce contamination and diffusion. Modern isotope techniques with better resolution and low detection limits are likely to provide more details compared to the preliminary work of the 1990s. With degrading permafrost and some specific pingos experiencing rapid change, many more sampling sites are likely to be identified. Based on Pingo 132, it is obvious that satellite data providing both optimal images and interferograms can systematically identify areas of degrading permafrost. This would allow us to identify suitable sites to collect samples of gas and water that originate from below the permafrost seal. Furthermore, satellite data can be used for preliminary dating of mud extrusions.

Finally, it must be emphasised that the changes observed over the last decades and years point towards a dynamic situation caused by climate change. This may potentially lead to much more frequent mud diapirism and emissions of gas in large parts of the Nuussuaq Basin when more permafrost degrades in the future. There is a strong need for many of the localities to be documented and monitored in detail. This has implications not only for petroleum exploration but also from a viewpoint of nature preservation as many new local ecosystems are likely to develop and change over time in the coming decades.

\section{Acknowledgements}

Analytical data are from many different field projects by GGU/GEUS with additional funding from Danish and Greenlandic authorities. Contributions came especially from the former Danish Ministry of Energy Research Program (EFP), the previous Mineral Resources Administration for Greenland in Copenhagen, the previous Bureau of Minerals and Petroleum in Nuuk and recently from the present Ministry of Industry, Energy, Research and Labour, Nuuk, Greenland. Close collaboration with industry over the years, especially grønArctic Energy Inc. and its enthusiastic manager Cam Hanna has been very useful. Practical help over many years and analytical support by John Boserup, Ditte
Kiel-Duhring, H. P. Nytoft and Christina Rosenberg Lynge are highly appreciated. Martin Krüger at Bundesanstalt für Geowissenschaften und Rohstoffe in Hannover is gratefully acknowledged for performing isotopic analyses of the pingo gas samples collected in 2019. We would like to thank Dietmar Backes from the University of Luxembourg for giving us access to PlanetScope imagery provided via the Planet's Education and Research program that has been used for generation of NDVI maps. Comments on the paper by the reviewers Chris Parry and Sverre E. Ohm were welcome.

\section{Additional information}

\section{Funding statement}

Samples from 2019 were collected on a field trip financed by Ministry of Industry, Energy, Research and Labour, Nuuk, Greenland. Other costs were paid by the Geological Survey of Denmark and Greenland.

\section{Author contribution}

FGC: writing the original draft (lead). JABK: analyses, presentation and discussion of oil geochemistry data. GD: contribution to historical data and petroleum exploration model. TL: analyses, presentation and discussion of water and gas geochemistry data. SS: analyses, presentation and discussion of satellite data.

\section{Additional files}

Six additional files are available online: https://doi.org/10.22008/FK2/ SO5VLD.

\section{References}

Bate, K.J. \& Christiansen, F.G. 1996: The drilling of the stratigraphic borehole Umiviik \#1, Svartenhuk Halvø, West Greenland. Grønlands Geologiske Undersøgelse Bulletin 172, 22-27.

Blumenberg, M. et al. 2016: Hydrocarbons from near-surface sediments of the Barents Sea north of Svalbard - indication of subsurface hydrocarbon generation? Marine and Petroleum Geology 76, 432-443. https://doi.org/10.1016/j.marpetgeo.2016.05.031

Bojesen-Koefoed, J.A. et al. 1997a: Seep data from onshore West Greenland. Danmarks og Grønlands Geologiske Undersøgelse Rapport 1997/34, 7 pp. Unpublished report. Geological Survey of Denmark and Greenland, Denmark.

Bojesen-Koefoed, J.A. et al. 1997b: Organic geochemistry and thermal maturity of sediments in the GRO\#3 well, Nuussuaq, West Greenland. Danmarks og Grønlands Geologiske Undersøgelse Rapport 1997/143, 18 pp. Unpublished report. Geological Survey of Denmark and Greenland, Denmark.

Bojesen-Koefoed, J.A. et al. 1999: Oil seepage onshore West Greenland: evidence of multiple source rocks and oil mixing. In: Fleet, A.J. \& Boldy, S.A.R. (eds): Petroleum geology of Northwest Europe: Proceeding of the 5th conference on the Petroleum Geology of Northwest Europe, Geological Society, London, UK, 305-314. https://doi. org/10.1144/0050305

Bojesen-Koefoed, J.A., Nytoft, H.P. \& Christiansen, F.G. 2004: Age of oils in West Greenland: was there a Mesozoic seaway between Greenland and Canada. Geological Survey of Denmark and Greenland Bulletin 4, 49-52. https://doi.org/10.34194/geusb.v4.4783

Bojesen-Koefoed, J.A. et al. 2007: Petroleum seepages at Asuk, Disko, West Greenland: implications for regional petroleum exploration. Journal of Petroleum Geology 30, 219-236. https://doi. org/10.1111/j.1747-5457.2007.00219.x

Bojesen-Koefoed, J.A. et al. 2018: Petroleum potential of the Upper Jurassic Hareelv Formation, Jameson Land, East Greenland. Geological Survey of Denmark and Greenland Bulletin 42, 85-113. https://doi. org/10.34194/geusb.v42.4314

Christiansen, F.G. 1993: Disko Bugt Project 1992, West Greenland. Grønlands Geologiske Undersøgelse Rapport 159, 47-52.

Christiansen, F.G. 2011: Greenland petroleum exploration: history, breakthroughs in understanding and future challenges. In: Spencer, A. et al. (eds): Arctic petroleum geology. Geological Society (London) Memoir 35, 647-661. https://doi.org/10.1144/M35.42 
Christiansen, F.G. \& Pulvertaft, T.C.R. 1994: Petroleum-geological activities in 1993: oil source rocks the dominant theme of the season's field programme. Grønlands Geologiske Undersøgelse Rapport 160, 52-56.

Christiansen, F.G. et al.1992: Renewed petroleum geological studies onshore West Greenland. Grønlands Geologiske Undersøgelse Rapport 155, 31-35.

Christiansen, F.G., Dam, G. \& Pedersen, A.K. 1994a: Discovery of live oil at Marraat, Nuussuaq, West Greenland - field work, drilling and logging. Grønlands Geologiske Undersøgelse Rapport 160, 57-63.

Christiansen, F.G., Bojesen-Koefoed, J.A. \& Nytoft, H.P. 1994b: Organic geochemistry of oil impregnated cores from the Marraat-1 well, Nuussuaq, West Greenland - comparison with surface samples. Open File Series Grønlands Geologiske Undersøgelse 94/8, 26 pp. Unpublished report. Geological Survey of Greenland, Greenland.

Christiansen, F.G. et al. 1994c: Shallow core summary sheets: Cretaceous sediments of Nuussuaq and Svartenhuk Halvø (GGU 400701-400712). Open File Series Grønlands Geologiske Undersøgelse 94/10, 31 pp. Unpublished report. Geological Survey of Greenland, Greenland.

Christiansen, F.G., Marcussen, C. \& Chalmers, J.A. 1995a: Geophysical and petroleum geological activities in the Nuussuaq - Svartenhuk Halvø area 1994 - promising results for an onshore exploration potential. Grønlands Geologiske Undersøgelse Rapport 165, 32-41.

Christiansen, F.G. et al. 1995b: Stratigraphy, sedimentology and geochemistry of cores and other samples from the GANW\#1 well, Nuussuaq, West Greenland, 52 pp. Report prepared for grønArctic Energy Inc. Regina, Saskatchewan, Canada.

Christiansen, F.G. et al. 1996a: Continued geophysical and petroleum geological activities in West Greenland in 1995 and start of onshore exploration programme. Grønlands Geologiske Undersøgelse Bulletin 172, 15-21.

Christiansen, F.G. et al. 1996b: Organic geochemistry of sediments, oils, and gases in the GANE\#1, GANT\#1, and GANK\#1 wells, Nuussuaq, West Greenland. Confidential Report (released 1 January 1997) prepared for grønArctic Energy, Inc., Calgary, Alberta, Canada. Danmarks og Grønlands Geologiske Undersøgelse Rapport 1996/23, 1-35.

Christiansen, F.G. et al. 1996c: The Marraat oil discovery on Nuussuaq, West Greenland: evidence for a latest Cretaceous - earliest Tertiary oil source rock in the Labrador Sea - Melville Bay region. Bulletin of Canadian Petroleum Geology 44, 39-54. https://doi.org/10.35767/ gscpgbull.44.1.039

Christiansen, F.G. et al. 1997a: Continued petroleum geological activities in 1996, and drilling of a deep exploration well. Geology of Greenland Survey Bulletin 176, 17-23. https://doi.org/10.34194/ggub.v176.5055

Christiansen, F.G., Bojesen-Koefoed, J.A. \& Laier, T. 1997b: Organic geochemistry of sediments and gases in the borehole Umiivik-1, Svartenhuk Halvø, West Greenland. Danmarks og Grønlands Geologiske Undersøgelse Rapport 1997/33, 16 pp. Unpublished report, Geological Survey of Denmark and Greenland, Denmark.

Christiansen, F.G. et al. 1998: Petroleum geological activities onshore West Greenland in 1997. Geology of Greenland Survey Bulletin 180, 10-17. https://doi.org/10.34194/ggub.v180.5079

Christiansen, F.G. et al. 2006: Comments on amounts of oil present (or once present) in the volcanic rocks on Disko and Nuussuaq, West Greenland. GEUS-NOTAT 08-EN-06-16, 27 pp. Unpublished memo, Denmark: Geological Survey of Denmark and Greenland. Supplementary file S6. https://doi.org/10.22008/FK2/SO5VLD

Dam, G. \& Christiansen, F.G. 1994: Well summary Marraat-1, Nuussuaq, West Greenland. Open File Series Grønlands Geologiske Undersøgelse 94/11, 26 pp. Unpublished report. Geological Survey of Greenland, Greenland.

Dam, G. \& Nøhr-Hansen, H. 1995: Sedimentology and stratigraphy of the sediments from cores drilled by Falconbridge Ltd. in 1994 at Serfat, northern Nuussuaq, West Greenland. Open File Series Grønlands Geologiske Undersøgelse 95/8, 18 pp. Unpublished report. Geological Survey of Greenland, Greenland.

Dam, G. \& Sønderholm, M. 1994: Lowstand slope channels of the Itilli succession (Maastrichtian - Lower Paleocene), Nuussuaq, West Greenland. Sedimentary Geology 94, 49-71. https://doi.org/10.1016/ 0037-0738(94)90146-5
Dam, G. \& Sønderholm, M. 1998: Sedimentological evolution of a fault-controlled Early Paleocene incised-valley system, Nuussuaq Basin, West Greenland. In: Shanley, K.W. \& McCabe, P.J. (eds): Relative role of eustasy, climate, and tectonism in continental rocks. Society of Economic Paleontologists and Mineralogists Special Publication 59, 109-121. https://doi.org/10.2110/pec.98.59.0109

Dam, G. et al. 1998: The oldest marine Cretaceous sediments in West Greenland (Umiivik-1, Svartenhuk Halvø) - record of the Cenomanian-Turonian anoxic event? Geology of Greenland Survey Bulletin 180, 128-137. https://doi.org/10.34194/ggub.v180.5096

Dam, G. et al. 2009: Lithostratigraphy of the Cretaceous-Paleocene Nuussuaq Group, Nuussuaq Basin, West Greenland. Geological Survey of Denmark and Greenland Bulletin 19, 1-171. https://doi.org/10.34194/ geusb.v19.4886

Drits, V.A. et al. 2007: Formation and transformation of mixed-layer minerals by Tertiary intrusives, West Greenland. Clays and Clay Minerals 55, 260-283. https://doi.org/10.1346/CCMN.2007.0550304

Etiope, G. 2015: Natural gas seepage: the earth's hydrocarbon degassing. 199 pp. Springer Verlag, Germany. https://doi. org/10.1007/978-3-319-14601-0

Faber, E. 1987: Zur Isotopengeochemie gasförmiger Kohlenwasserstoffe. Erdöl, Erdölgas \& Kohle 103, 210-218.

Henderson, 1969: Oil and gas prospects in the Cretaceous-Tertiary basin of West Greenland. Grønlands Geologiske Undersøgelse Rapport 22, 1-63.

Holba, A.G. et al. 1998: Application of 24-norcholestanes for constraining source age of petroleum. Organic Geochemistry 29, 1269-1283. https://doi.org/10.1016/S0146-6380(98)00184-3

Jenden, P.D. \& Kaplan, I.R. 1989: Origin of natural gas in Sacramento basin, California. American Association of Petroleum Geology Bulletin 73, 431-453. https://doi.org/10.1306/44B4 9FC9-170A-11D7-8645000102C1865D

Kierkegaard, T. 1998: Diagenesis and reservoir properties of Campanian-Paleocene sandstones in the GANT\#1 well, western Nuussuaq, central West Greenland. Geology of Greenland Survey Bulletin 180, 31-34. https://doi.org/10.34194/ggub.v180.5083

Kristensen, L. \& Dam, G. 1997: Lithological and petrophysical evaluation of the GRO\#3 well, Nuussuaq, West Greenland. Danmarks og Grønlands Geologiske Undersøgelse Rapport 1997/156, 30 pp. Unpublished report. Geological Survey of Denmark and Greenland, Denmark.

Kuijpers, A. et al. 2001: Late Quaternary circulation changes and sedimentation in Disko Bugt and adjacent fjords, central West Greenland. Geology of Greenland Survey Bulletin 189, 41-47. https://doi. org/10.34194/ggub.v189.5153

Hjuler, M.L. et al. 2017: Potential hydrocarbon reservoirs of AlbianPaleocene age in the Nuussuaq Basin, West Greenland. Geological Survey of Denmark and Greenland Bulletin 38, 49-52. https://doi. org/10.34194/geusb.v38.4408

Laier, T. 1994: Analyse af gas- og vandprøver fra Grønland, januar 1994. DGU Rapport, 7 pp. Unpublished report. Geological Survey of Denmark, Denmark. Supplementary file S1. https://doi.org/10.22008/FK2/SO5VLD

Mazzini, A. \& Etiope, G. 2017: Mud volcanism: an updated review. Earth Science Reviews 168, 81-112. https://doi.org/10.1016/j.earscirev.2017. 03.001

Mazzini, A. et al. 2011: Fluid origin, gas fluxes and plumbing systems in the sediment-hosted Salton Sea Geothermal System (California, USA). Journal of Volcanology and Geothermal Research 205, 67-83. https:// doi.org/10.1016/jjvolgeores.2011.05.008

Mikkelsen, N.E. et al. 2012: Methane and possible gas hydrates in the Disko Bugt region, central West Greenland. Geological Survey of Denmark and Greenland Bulletin 26, 69-72. https://doi.org/10.34194/ geusb.v26.4764

Nielsen, T. et al. 2014: Fluid flow and methane occurrences in the Disko Bugt area offshore West Greenland: indications for gas hydrates? Geo-Marine Letters 34, 511-523. https://doi.org/10.1007/ s00367-014-0382-2

Nytoft, H.P., Bojesen-Koefoed, J.A. \& Christiansen, F.G. 2000: C26 and C28-C34 28-norhopanes in sediments and petroleum. Organic Geochemistry 31, 25-39. https://doi.org/10.1016/S0146-6380(99)00150-3 
Nytoft, H.P. et al. 2002: Oleanane or lupane - reapraisal of the presence of oleanane in Late Cretaceous - Tertiary oils and sediments. Organic Geochemistry 33, 1225-1240. https://doi.org/10.1016/S0146-6380(02)00138-9

Pedersen, A.K., Larsen, L.M. \& Dueholm, K. 2002: Geological section along the north side of the Aaffarsuaq valley and central Nuussuaq, central West Greenland. 1: 20000 coloured geological sheet. Copenhagen: Geological Survey of Denmark and Greenland.

Pedersen, A.K., Larsen, L.M. \& Pedersen, G.K. 2017: Lithostratigraphy, geology and geochemistry of the volcanic rocks of the Vaigat Formation on Disko and Nuussuaq, Paleocene of West Greenland. Geological Survey of Denmark and Greenland Bulletin 39, 1-244. https://doi. org/10.34194/geusb.v39.4354

Pedersen, A.K., Larsen, L.M. \& Pedersen, G.K. 2018: Lithostratigraphy, geology and geochemistry of the volcanic rocks of the Maligât Formation and associated intrusions on Disko and Nuussuaq, Paleocene of West Greenland. Geological Survey of Denmark and Greenland Bulletin 40, 1-239. https://doi.org/10.34194/geusb.v40.4326

Pissart, A. 1988: Pingos: an overview of the present state of knowledge. In: Clark, M.J. (ed.): Advances in periglacial geomorphology, 279-297. New York: John Wiley and Sons.
Porter, C. et al. 2018: ArcticDEM V2, https://doi.org/10.7910/DVN/OHHUKH, Harvard Dataverse

Radke, M., Willsch, N. \& Welte, D.H. 1980: Preparative hydrocarbon group type determination by automated medium pressure liquid chromatography. Analytical Chemistry 52, 406-411. https://doi.org/10.1021/ ac50053a009

Rosen, P.A. et al. 2000: Synthetic aperture radar interferometry. Proceedings of the IEEE 88, 333-382. https://doi.org/10.1109/5.838084

Rosenkrantz, A., Münther, V. \& Henderson, G. 1974: Geological map of Greenland, 1:100 000, Agatdal, 70 V.1 Nord. Copenhagen: Geological Survey of Greenland.

Schoell, M. 1984: Stable isotopes in petroleum research. In: Brooks, J. \& Welte, D. (eds): Advances in petroleum geochemistry 1, 215-245. London: Academic Press. https://doi.org/10.1016/ B978-0-12-032001-1.50009-2

Sørensen, E.V. et al. 2017: Inversion structures as potential petroleum exploration targets on Nuussuaq and northern Disko, onshore West Greenland. Geological Survey of Denmark and Greenland Bulletin 38, 45-48. https://doi.org/10.34194/geusb. v38.4406 